\author{
Игорь Пильщиков \\ Калифорнийский университет в Лос-Анджелесе \\ Московский государственный университет им. М. В. Ломоносова \\ Таллиннский университет \\ pilshchikov@ucla.edu
}

Igor Pilshchikov

University of California, Los Angeles

Lomonosov Moscow State University

Tallinn University

pilshchikov@ucla.edu

\title{
РУССКИЙ МАТ: ЧТО МЫ О НЕМ ЗНАЕМ? (О ПРОИСХОЖДЕНИИ И ФУНКЦИЯХ РУССКОЙ ОБСЦЕННОЙ ИДИОМАТИКИ)
}

\section{RUSSIAN "MAT": WHAT DO WE KNOW ABOUT IT? (ON THE ORIGIN AND FUNCTIONS OF RUSSIAN OBSCENITIES)}

В статье обсуждаются диахронические изменения в морфологии, акцентологии, семантике и стилистике, которые претерпела русская обсценная идиоматика. Обнаружено, что вплоть до конца XIX века в фольклоре, неподцензурной литературе и бытовой речи матерные слова употреблялись преимущественно в прямом, т. е. материальном значении, а количество слов, образованных с помощью базовых обсценных корней, было ограниченным. Главными механизмами матерных инноваций в XX-XXI вв. стали метафоризация (свободный перенос значений) и прономинализация (приобретение контекстных значений). Они привели к деривационному взрыву, когда появилась возможность образовывать сотни новых обсценных слов от весьма ограниченного числа корней. Вместе с тем из современного употребления выпали некоторые слова старого матерного пула. Еще один важный механизм «матообразования» - последовательные и / или накладывающиеся друг на друга процессы дисфемизации и эвфемизации, отразившиеся в изменении лексико-семантических и акцентных парадигм некоторых матерных слов и их эвфемизмов. В то же время примеры анафорической редупликации, резко активизировавшейся в последние полвека, обнаруживаются уже в текстах первой половины XIX столетия. В статье также рассматривается эволюция функций мата в литературе XVIII-XX вв. и, в частности, употребление мата в произведениях Баркова, Пушкина и Бродского.

Ключевые слова: русская обсценная идиоматика, диахронические изменения в морфологии, акцентологии, семантике и стилистике мата, механизмы инноваций, функции мата в литературе XVIII-XX вв. 
This article analyzes diachronic morphological, accentual, semantic and stylistic changes in the Russian obscene vocabulary and phraseology (mat). Before the late nineteenth century, obscenities in folklore, uncensored literature and everyday speech were predominantly used in their direct, i. e. material meaning. The number of words derived from basic obscene roots was limited. Metaphorization (free change of meaning by association) and pronominalization (acquiring contextualized meanings) are the primary mechanisms of innovation in twentieth- and twenty-first-century mat. Both are accompanied by a derivational explosion when it became possible to create hundreds of new obscenities derived from a small number of roots. Meanwhile, several roots previously used to form obscenities became obsolete. The consecutive and/or overlapping processes of disphemization and euphemization were yet another important mechanism of innovation that shaped changes in both the semantic and accentual paradigms of some obscene words and their euphemisms. At the same time, traces of anaphoric reduplication, another phenomenon unusually active in contemporary mat, can be detected in the nineteenth century. The article also discusses the evolution of the functions of mat in literature from the eighteenth to the twentieth century and, in particular, the use of mat in the poetical works of Barkov, Pushkin and Brodsky.

Key words: Russian obscenities, diachronic morphological, accentual, semantic and stylistic changes, mechanisms of innovation, functions of "mat" in 18th-, 19th- and 20thcentury Russian literature.

Лексикографъ не имъетъ права урђзывать и кастрировать «живой языкъ». Разъ извђстныя слова существуютъ въ умахъ громаднаго большинства народа и безпрестанно выливаются наружу, лексикографъ обязань занести ихъ въ словарь, хотя бы противъ этого возставали и притворно негодовали всь лицемђры и тартюфы...

(Бодуэн-де-Куртенэ 1909: VI)

\section{1. Прагматика vs. семантика: брань vs. обсценность}

Начнем с определения. Мат - это обсценная экспрессивная табуированная лексика и фразеология русского языка. Мат содержательно связан с сексуальной жизнью и ее обозначениями в языке («обсценность»). Мат выражает сильные эмоции - именно это делает его необычайно мощным стилистическим средством («экспрессивность»). Наконец, мат запрещен к употреблению в целом ряде социальных контекстов («табуированность»).

Мы привыкли к словосочетанию «матерная брань»: многие думают, что мат - это брань, а брань - это мат. Но это не так: «Брань может быть не обсценной (пошел ты к черту!), обсценные выражения могут употребляться не в составе собственно ругательств (хуй ты там заработаешь)» (Левин 1986: 62). Иначе говоря, определение «обсценный» относится к области значения слов (их семантики), а определение «бранный» — к области их предназначения (прагматики).

Это разделение очень важно. С одной стороны, не всякое употребление мата оскорбительно. С другой стороны, оскорбить можно вообще не используя никаких ругательств, а употребляя литературные, но обидные для конкретного человека слова. И напротив, грубые и вообще пейоративные 
слова в надлежащем контексте могут выражать одобрение, нежность и другие позитивные чувства.

В каких контекстах использовать мат нельзя, а в каких можно? Иные скажут, что матерные слова нельзя употреблять никогда — это абсолютизация табу. Другие скажут, что есть контексты, в которых мат уместен, и есть такие, в которых он абсолютно неприемлем.

В течение долгого времени демаркационная линия проходила между текстами печатными и непечатными. Отсюда эвфемизмы «непечатные выражения», «выражаться непечатно» наряду с «нецензурные выражения», «выражаться нецензурно». Это сразу подсказывает нам, по какой оси проходит разделение: «официальное vs. неофициальное». Печатный текст имеет более высокий официальный статус. То, что распространяется в печатном виде, имеет более высокое социальное значение, чем то, что «просто» говорится. Поэтому не всё, что можно сказать, можно записать и тем более напечатать.

Далее, имеется гендерная дифференциация. Кто-то считает, что мат допусти́м, если он исходит из уст мужчины и недопусти́м, если он исходит от женщины: женщины вообще не должны употреблять мат. Другие полагают, что мат допусти́м при общении между мужчинами, а в присутствии женщины он уже не допусти́м. Кто-то дозволяет женщинам матерное словоупотребление в общении друг с другом, но не в общении с мужчинами. Есть и возрастная дифференциация: считается, что взрослый человек может пользоваться матом, а ребенку употреблять мат не пристало.

Таким образом, единой системы социально приемлемых контекстов для употребления мата, по-видимому, не существует, хотя некоторая тенденция наблюдается: «право на мат» имеют доминирующие акторы, то есть лица с более «высоким» (с точки зрения данной социальной группы) общественным, гендерным и возрастным статусом (Жельвис 2001: 66).

\section{2. Обсценность, скатология, бласфемия}

Мат описывает преимущественно сексуальную сферу жизни. Более того, матерные корни в прямом их значении описывают только сексуальную сферу. При этом мы видим (точнее, слышим), что слова хуй и пизда звучат гораздо более грубо, чем слова говно, срать, жопа или какие-то другие слова, не связанные с сексуальностью. Похожие явления есть и в других языках. Но есть и отличия.

Во-первых, существует скатологическая лексика - слова, описывающие испражнения. Она очень активна в целом ряде языков - например, в германских (немецкий, английский) и романских (французский, итальянский): shit, Scheiße, merde, merda и т. д. По своей инвективной силе германская скатологическая лексика значительно превосходит романскую и соответствует русской обсценной (Timroth 1983: 109; Мокиенко 1994: 58-61; Жельвис 2001: 170, 237-241; Панасюк 2005). В тех же языках есть и грубая 
сексуальная лексика (общеизвестный пример - английское fuck). Но в отличие от русского языка она не табуирована - это грубое просторечие, которое гораздо проще находит в себе путь в печатные тексты, кинофильмы и пр. Из славянских языков чешский, в наибольшей степени подвергшийся германскому влиянию, больше культивирует скатологическую лексику, чем, например, польский или русский. Мы знаем это по роману Ярослава Гашека о бравом солдате Швейке, где очень много скатологии, и звучит она для русского уха довольно необычно 1 .

Во-вторых, имеется такое явление, как бласфемия - кощунство. В итальянском языке многочисленные кощунственные выражения (bestemmia) звучат намного грубее, чем обсценные сексуальные: последние не столько оскорбительны, сколько грубо комичны. А бласфемия по своей экспрессивной табуированности приближается к русскому мату.

Итак, табуированность и экспрессивность могут быть связаны не с сексуальностью, а с кощунством или скатологией. Такие сферы экспрессивной табуированной лексики представляют собой особые семиотические системы, которые в каждой культуре устроены по-разному. Однако это разнообразие не бесконечно, поэтому встречаются повторения и сходства. Кроме того, культуры контактируют друг с другом и оказывают друг на друга взаимное влияние.

\section{3. Мат, миф и ритуал}

Достоверно ответить на вопрос о происхождении русского мата непросто - не только потому, что в поисках ответа на этот вопрос мы уходим в глубокую древность, но и потому, что мы имеем дело с такой сферой языка, которая плохо закрепляется в письменной форме. Мат трудно зафиксировать, поскольку сами носители соответствующей фразеологии не готовы употреблять ее свободно в ситуации официального общения с опрашивающим (лингвистом или этнографом). Всё, что мы знаем о том, как она употребляется сейчас и как она употреблялась раньше - это обрывки информации, из которых приходится реконструировать общую картину.

Реконструкцию функций мата в древнерусскую эпоху предложил Б. А. Успенский, который на материале старых письменных источников (XVI-XVII веков) и записей фольклора, сделанных в XIX-XX веках, связал происхождение матерщины с ритуальным сквернословием (Успенский $1981 ; 1994)$. В данном случае речь идет о языческом земледельческом ритуале, а именно о ритуальном оплодотворении земли, которое выражалось через миметическое и вербальное совокупление с ней. Цель аграрного ритуала - утверждение перманентности жизнеобеспечивающего сельскохозяйственного процесса. С точки зрения носителей ритуальной культуры, ритуал нужен для того, чтобы процесс не останавливался, чтобы плодородие земли не иссякло.

1 На русский язык роман Гашека перевел П. Г. Богатырёв. 
Предполагается, что ритуальное употребление мата у самих его носителей должно было сопровождаться табу на употребление матерщины вне ритуала. Типологической параллелью к словесному описанию совокупления с землей является эсхрология - античное ритуальное сквернословие (Успенский 1994: 71; ср. Пропп 1976: 194-196). Если это так, то неприятие табуированной лексики в русском языке можно связать с борьбой христианской церкви против двоеверия, очень распространенного в русской крестьянской среде вплоть до относительно недавнего времени.

Носители народной культуры находили новые обоснования для запрета матерного сквернословия, утрачивающего свою связь с ритуалом. Распространились поверья о том, что ругаясь неуместно, человек оскорбляет мать: и мать сыру землю, и богородицу, которая в ситуации двоеверия ассоциируется с матерью-землей, и свою собственную мать. Оскорбление чужой матери Б. А. Успенский реконструирует как следующую стадию использования мата - стадию перехода от ритуальной функции к инвективной (функции оскорбления). Таким образом, использование матерщины как оскорбительной брани имеет вторичный характер и представляет собой позднейшую стадию существования мата (Успенский 1994: 101).

Разумеется, реконструкция генезиса и культовых функций мата остается лишь гипотезой. Вполне вероятно, что в каких-то случаях мы имеем дело со вторичной мифологизацией мата или полемическим приписыванием ему функций, которых он в действительности не имел (Панченко 2005). Однако общий вывод Б. А. Успенского о процессе десакрализации и профанизации мата представляется убедительным.

Ритуальные тексты постепенно теряли связь с ритуалами и начинали функционировать самостоятельно, приобретая новые функции. По всей видимости, это происходило не только с матерной идиоматикой, но и с другими нарративами, предположительно отколовшимися от мифа и ритуала, - например, с «заветными» сказками (Успенский 1996) и волшебными сказками (Пропп 1946). Утратив связь с ритуалом, мат начал развивать свои экспрессивные и обсценные потенции.

\section{4. «Свое» и «чужое». Генеалогия мата}

Предложенная Б. А. Успенским модель объясняет парадокс русского мата: это, с одной стороны, что-то интимно свое, специфичное для нашей культуры, то, чем мы, носители русской культуры, пользуемся каждый день, а, с другой стороны, мат - это то, что запрещено, чего нельзя ни произнести, ни написать, то, за употребление чего можно подвергнуться преследованию и наказанию. Иначе говоря, мат, будучи «своим», воспринимается одновременно как нечто «чужое». В древнерусских источниках матерная речь описывается как «еллинская» (то есть языческая) и «жидовская»; Успенский сопоставил эти старинные представления с распространившимся в XX веке поверьем о «монголо-татарском» происхождении 
мата: мат воспринимается как нечто чужое, привнесенное извне и поэтому якобы чуждое духу русского языка (Успенский 1994: 58-61).

В последние годы едва ли не любой разговор о мате в прессе начинается с вопроса: действительно ли мат принесли на Русь «татаро-монголы»? Когда обнаружились берестяные грамоты XII — начала XIII веков, в которых фигурируют матерные слова, журналисты первым делом сообщили публике, что этой находкой лингвисты наконец-то доказали «не монголо-татарское» происхождение мата, поскольку грамоты относятся к домонгольскому периоду (см., например: Ромашенкова, Усманов 2005).

В действительности лингвисты никогда не считали, что мат имеет монголо-татарское происхождение. Абсолютное большинство слов, составляющих или составлявших в разные периоды времени матерный «пул» (pool) русского языка, - это исконно славянская лексика, она есть не только в русском, но и (с вариациями) - в других славянских языках. Для нескольких матерных слов с той или иной степенью убедительности восстанавливаются и общеиндоевропейские праформы. Таким образом, русские матерные слова уходят своими корнями (и в метафорическом, и в сугубо лингвистическом смысле) в индоевропейскую древность.

Каковы основные матерные корни и какова их этимология?

Сегодняшнюю языковую ситуацию определил закон против публичного использования «нецензурной брани» № 101-Ф3, инициированный группой депутатов во главе с председателем комитета Госдумы по культуре Станиславом Говорухиным и вступивший в силу 1 июля 2014 г. ${ }^{2}$ Годом раньше был принят закон №34-Ф3, ограничивающий употребление «нецензурной брани» в СМИ, вступивший в силу 19 апреля 2013 г. ${ }^{3}$ Поскольку в указанных законах конкретное содержание понятия «нецензурная брань» не раскрывается, их применение основывается на специальном разъяснении Роскомнадзора ${ }^{4}$, процитированном в Известиях 25 декабря 2013 г., согласно которому к употреблению не допускаются следующие слова:

Нецензурное обозначение мужского полового органа, нецензурное обозначение женского полового органа, нецензурное обозначение процесса совокупления и нецензурное обозначение женщины распутного поведения, а также все образованные от этих слов языковые единицы. (Зыков, Кондратьев 2013)

Таким образом, запрещены слова $х у \check{u}$, пизда, ебать, блядь и все производные от них.

2 Федеральный закон от 5 мая 2014 г. № 101-Ф3 «О внесении изменений в Федеральный закон “О государственном языке Российской Федерации” и отдельные законодательные акты Российской Федерации в связи с совершенствованием правового регулирования в сфере использования русского языка».

3 Федеральный закон от 5 апреля 2013 г. № 34-Ф3 «О внесении изменений в статью 4 Закона Российской Федерации “О средствах массовой информации” и статью 13.21 Кодекса Российской Федерации об административных правонарушениях».

4 Полное название ведомства: «Федеральная служба по надзору в сфере связи, информационных технологий и массовых коммуникаций (Роскомнадзор)». 
Одной из первых жертв нового законодательства стала беседа о мате редактора отдела науки «Ленты.ру» с автором этих строк, опубликованная 2 апреля 2013 г. (Пильщиков, Коняев 2013)5. Она была удалена с сайта 8 июля того же года по требованию Роскомнадзора в соответствии с письмом № 05КМ-15586 от 05.06.20136. И запрет научно-популярного интервью, удививший западноевропейских русистов (см. Rann 2014: 584), и сама формулировка запрещения, использующая парафразы вместо прямого называния запретных слов, наглядно демонстрируют интереснейшую особенность функционирования мата, отмеченную Б. А. Успенским: «матерщина считается в принципе недопустимой для произнесения (или написания) даже и в том случае, когда она воспроизводится от чужого имени, как чужая речь», поскольку матерное высказывание, в отличие от любых других высказываний на русском языке, никогда «не становится чистой цитатой» (Успенский 1981: 49; 1994: 57). Действительно, закон, в котором, по идее, должен быть приведен список слов и корней, запрещенных к публичному употреблению, невозможно сформулировать, поскольку публикация такого закона станет первым фактом его нарушения.

Но вернемся к вопросу об этимологии.

Необходимо разграничить два аспекта - этимологию и историю слов. Этимология изучает происхождение слова либо из общего праязыкового фонда (например, праиндоевропейского для индоевропейских языков), либо, в случае заимствования, устанавливает сам момент заимствования, перехода слова из одного языка в другой. История слова - это то, что происходит со словом, когда оно уже попало в язык. Некоторые лингвисты относят недавние заимствования не к собственно этимологии, а к истории слов. Эта история может быть довольно причудливой: слово может переосмысливаться, могут меняться его значение, фонетическая форма, стилистическая принадлежность. Вопросами этимологии занимается сравнительно-историческое языкознание, а историей слов - историческая лексикология, историческая стилистика и другие лингвистические дисциплины, изучающие историю конкретного языка.

Этимология - почти всегда реконструкция. Когда у группы родственных языков (например, у романских или славянских языков) обнаруживается или постулируется язык-родитель (в наших примерах: латынь для романских языков и праславянский язык - для славянских), то предполагается, что в идеальном случае, когда нет дополнительных возмущающих воздействий, те вариации, которые мы наблюдаем в современных родственных языках, отражают некоторый, когда-то существовавший инвариант. Аналогичным образом восстанавливается еще более древнее языковое состояние (например, для латыни, древнегреческого, санскрита, праславян-

5 Пользуюсь случаем сказать, что в интервью были некоторые фактические неточности, исправленные в настоящей статье.

6 «Роскомнадзор запретил три статьи “Ленты.py”». http://lenta.ru/news/2013/07/08/ swearwords/ 
ского и прагерманского - гипотетический праиндоевропейский язык). Иногда, с точки зрения неквалифицированного наблюдателя, сходство между родственными словами совершенно неочевидно, потому что это не сходство звуков в их нынешнем состоянии, а установленное соответствие, проверенное на многих и многих парах и цепочках слов, установленные правила перехода, условия перехода одних звуков в другие. Звучать родственные слова в разных языках могут совершенно по-разному.

Надежная этимология слова $x y \check{u}$, предложенная еще в начале XX века датским языковедом Хольгером Педерсеном (Pedersen 1908) ${ }^{7}$, безоговорочно принята современными лингвистами. Она включена в Этимологический словарь славянских языков под редакцией О. Н. Трубачева (ЭССЯ 1981, 8: 114). Вошла она и в оригинальное немецкое издание этимологического словаря Макса Фасмера, вышедшее в 1950-е годы в Западной Германии (Vasmer 1958, III: 277). Однако из советского издания фасмеровского словаря, опубликованного в русском переводе О. Н. Трубачева с его же дополнениями и поправками (Фасмер 1964-1973), матерные слова были исключены по настоянию редакции, несмотря на то, что они «восходят еще к праславянскому периоду и имеют различные балтийские и некоторые другие индоевропейские соответствия», а «один глагол имеет несомненное праиндоевропейское происхождение» (Трубачев 1978: 21).

Слово хуй связано закономерным фонетическим и морфологическим чередованием со словом хвоя (*skou-i-o/*sku-oi-a $>*_{x u j b} / *_{x}$ хоја). Одно из этих слов мужского рода, другое женского, и возможность такого чередования подтверждена аналогичными языковыми явлениями. Базовое значение корня, по-видимому, - 'шип, колючка' (ср. ЭССЯ 1981, 8: 126). Слово $x y \check{и ~ п р е д с т а в л е н о ~ и ~ в ~ н е к о т о р ы х ~ д р у г и х ~ с л а в я н с к и х ~ я з ы к а х, ~ к о р е н ь ~ и м е е т ~}$ индоевропейские параллели. «Хотя и косвенным, но, видимо, наиболее ранним свидетельством существования данной лексемы со значением фаллоса в славянских языках» (Живов 2006: 211 примеч. 4) могут быть примеры использования аугмента -ть в 3-м лице множественного числа имперфекта на -ахоу/-лхоу перед энклитическим местоимением и для эвфонического устранения обсценных звукосочетаний хоу-и. В первой половине XII века в евангельских текстах, предназначавшихся для литургического чтения, звукосочетание хоу-и последовательно заменяется на хоу-ть-и (см. Живов 2006).

Слово пизда́ - безусловно, общеславянское - также, вероятно, восходит к праиндоевропейской древности (Vasmer 1955, II: 355). Его дальнюю этимологию предложил в 1968 году ведущий американский индоевропеист Эрик П. Хэмп (Наmp 1968). По Хэмпу, праславянская *pizda и ее родственницы восходят к праиндоевропейскому *písdeh. Э. Это композит, состоящий

7 Статья была опубликована в сборнике к 70-летию основателя современной палеославистики Ватрослава Ягича. 
из приставки *h $h_{1} е р i$ со значением 'на'8 (от которой сохранился элемент *pi) и корня со значением 'сидеть' (*s(e)d-). Таким образом, обсценное слово было первоначально эвфемизмом: «то, на чем сидят». Его образование, согласно этой гипотезе, находит аналог в образовании слова гнездо, в котором тому же корню предшествует приставка *ni со значением 'вниз' (гнездо «то, в чем сидят») $)^{9}$. Примеры из берестяных грамот - с середины XII века ${ }^{10}$.

«Главный» матерный глагол - eбámь, самый бесспорный, зафиксированный в древнеписьменных индоевропейских языках: यभति (yábhati) в санскрите, oì $\varphi$, oí $\varphi \dot{c} \omega$ (oiphō, oiphéó) в древнегреческом (Vasmer 1953, I: 388; ЭССЯ 1981, 8: 188). У русского глагола было две неопределенных формы - ети́ (праслав. *jěbti) и ебámu (праслав. *jěbati). Инфинитив ети́ (которому соответствует форма настоящего времени ебу́ и форма прошедшего времени ёб) представляет атематическое спряжение на *-bti ${ }^{11}$, тогда как основа инфинитива еба́mи, еба́mь (наст. вр. ебáю, прош. вр. еба́л) распространена итеративным (т. е. обозначающим многократное действие) суффиксом - $a$-. Форма с - $a$ - тоже древняя - ее презентная форма представлена уже в новгородской берестяной грамоте № 330, датируемой концом XIII века ${ }^{12}$. Однако в XVIII-XIX веках инфинитив ебать был более редок, чем сейчас: например, у Пушкина и авторов его круга он не встречается вовсе.

B XIX-XX веках эти две парадигмы слились в одну: тематическая форма презенса ебаю, ебает оказалась утрачена - остались только ебу, ебёт, но соответствующий им инфинитив ети был вытеснен инфинитивом ебать. Наши современники уже не понимают, что ети(ть) твою мать вовсе не более мягкое и приемлемое, как им кажется, выражение по срав-

8 Ср. др.-греч. приставку غ̇лt- 'на(д)-’, знакомую нам по грецизмам эпиграмма, эпиграф, эпидермис, эпителий и др.

9 Обе этимологии и аналогия между ними приняты в Этимологическом словаре славянских языков (ЭССЯ 1979, 6: 172) - в статье «*gnе̌zdo» (до буквы Р словарь еще не дошел). О других этимологиях слова пизда см. Oguibénine 2016: 226-228.

10 См.: ДБГ, № Смол. 15, http://gramoty.ru/birchbark/document/show/smolensk/15/; c опечаткой в транскрипции: Асташова, Зализняк 1998: 340-341. Другой пример см. в примеч. 19 ниже.

11 У двух других глаголов такого типа - грести́ (наст. вр. гребу́) и скрести́ (наст. вр. скреб $)$ - инфинитив впоследствии получил аналогический исход -сти вместо исконного -ти; ср. диалектное и просторечное ебсти́.

12 Там написано: «гуска сологал гуска гозу єбае ... залАко хусту», т. е. 'гузка (задница?) сологая (прелюбодействующая?) ебет другую, задрав одежду’. См. ДБГ, № 330, http://gramoty.ru/birchbark/document/show/novgorod/330/; Зализняк 2000: 99-100. В этой грамоте трудности для понимания создают все слова, кроме интересующего нас обсценного глагола (Антропов 2021).

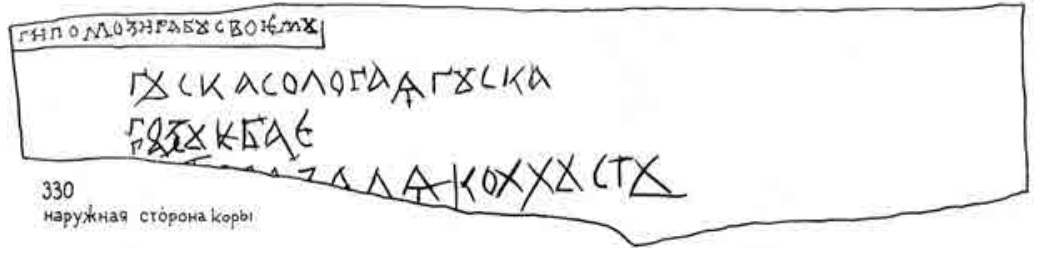


нению со своим нестяженным аналогом (Осипов 1991: 42-43). Кстати, удвоение суффикса (-mu+-mb) в форме ети́ть - по-видимому, следствие непонимания говорящими формальных грамматических характеристик формы emu ${ }^{13}$ : многие носители русского языка уже не опознают его как неопределенную форму глагола. Интересно, что у ети́ была девокализованная форма - eть. Не умея образовать от глагола ехать правильный императив езжай, многие наши современники безо всякого смущения произносят ошибочное $е д b$ (звучит как «еть»). Нынешние носители языка не понимают, что бастардная форма едь омофонична глаголу еть, то есть «ебать», - еще одно свидетельство постепенного ухода обсуждаемой формы из языка.

Форма ёб сохраняется в сегодняшнем языке преимущественно в составе выражения ёб твою мать и часто не осознаётся как форма прошедшего времени, поскольку в качестве «стандартного» претерита используется форма еба́л (Пушкин и его современники употребляли обе формы с равным удовольствием). Из атематических форм прошедшего времени наибольшую жизнеспособность проявили ебла́сь и ебли́сь, широко циркулирующие наряду с тематическими еба́лась и еба́лись.

Некоторые префиксальные дериваты обсуждаемого глагола изменили свое значение. Так, в конце февраля 1828 г. Пушкин писал С. А. Соболевскому «о M-de Кернъ, которую съ помощію божіей я на-дняхъ уебъ» (Пушкин 1908, II: 60). В современном языке атематическая форма отсутствует, а глагол уебámb, получивший новые переносные значения типа 'ударить' («уеба́л ему по морде/в морду»; ср. въеба́л) и 'уйти’ («он куда-то уеба́л»)14, больше не используется как глагол с семантикой копуляции, тогда как «старое» (то есть буквальное) значение передается другими приставочными образованиями - отъеба́mь и вь́ебать (Razvratnikov 1979: 202).

История слова блядь интересна тем, что оно пополнило собою матерный пул, куда первоначально не входило. В XVI-XVII веках это слово принадлежало литературному языку и даже относилось к высокому регистру. Этимология слова блядь совершенно прозрачна: в нем отразилась другая степень чередования корневого согласного по сравнению с родственным ему словом блуд, которое есть во всех славянских языках. Чередование выглядит следующим образом: *blods (с $o$ носовым, который в русском языке перешел в [u]) дает старославянское блждъ и русское блудъ; *blędb (с $e$ носовым, который в русском языке перешел в ['a]) дает старославянское блАдь и русское блядь (Vasmer 1953, I: 95-97; ЭССЯ 1975, 2: 114-115, 125128). Слова с тем же корнем - блудить, блуждать, заблуждаться. Базовое значение корня - 'ошибка': пойти не туда (блуждать, заблудиться), сделать неверное умозаключение (заблуждаться).

Другое значение, которое фиксируется и в старославянском языке, и в древнерусском, - это 'распутство, разврат'. Не позднее конца XII начала XIII века существительное блядь получает известное ныне значе-

13 Предположение С. Г. Болотова. К ети́mь ср. эвфемистический пароним едри́mь.

14 Ср. «Уеби́сь ('уйди') отсюда!» 
ние: ‘блудница, распутная женщина' и далее 'продажная женщина, проститутка'. Вероятная филиация значений: 'ошибка' $\rightarrow$ 'обман' $\rightarrow$ 'распутство' и 'обманщик; обманщица' $\rightarrow$ 'распутница' (ср. Срезневский 1893, I: 173) - «название действия, с последующим переходом в разряд имен деятеля» (ЭССЯ 1975, 2: 115). В последнем значении оно употреблено в одной из грамот, относящихся к началу XIII века. Это грамота из Новгорода № 531, в которой сказано, что некто оскорбил женщину, назвав ее «ко[у]ровою и доцере бллдею» (т. е. ее «курвою, а дочь блядью») $)^{15}$.

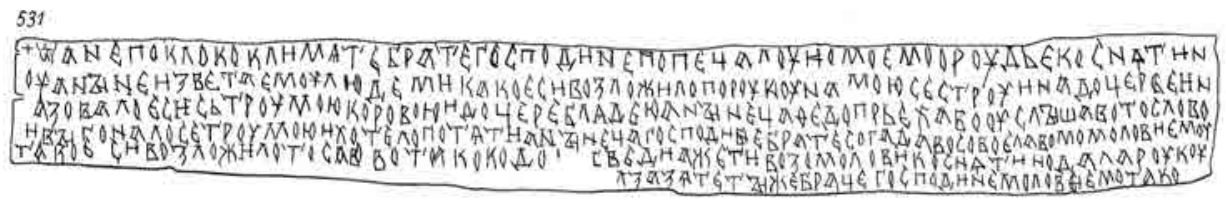

Итак, на базе разошедшейся полисемии образовалась омонимия: блядь 'ошибка; заблуждение; ложь' vs. блядь 'распутница' (Аникин 2009: 277278). В течение долгого времени два значения существовали параллельно, оказавшись в результате на противоположных стилистических полюсах. Если в конце XVII века слово блядь в значении 'заблуждение' было еще активно, то к середине XVIII века высокое слово полностью вышло из употребления и в ходу остался только его грубо-просторечный омоним (Словарь РЯ XVIII 1984, 2: 72). Позже, в середине XIX века, слово блядь становится табуированным, то есть матерным; во избежание ненужных ассоциаций церковнославянские слова с этим корнем могут изыматься из литургических текстов (Живов 1996: 508). До этого, в период примерно с 1740-х по 1830-е годы, оно было менее грубым, чем слова хуй, пизда и ети. Этим объясняется включение слова блядь в те словари, из которых уже изгнаны слова хуй, пизда, ети и их производные.

Слово блядь и его дериваты еще представлены в словаре современника Державина Ивана Нордстета и в словаре современника Пушкина Филиппа Рейфа (Нордстет 1780, I: 36-37; Рейф 1835, I: 35). Оно считается грубым и просторечным, но не обсценным, что стилистически сопоставимо, например, со словом жопа, которое также включено в эти словари (Нордстет 1780, I: 199; Рейф 1835, I: 312). Обсценных слов - таких, как хуй или пизда - у Нордстета и Рейфа уже нет. А в советском издании словаря Фасмера, из которого были исключены обсценные лексемы, слово блядь отсутствует как бы наполовину: сама вокабула блядь изъята, но в соседних вокабулах блуд и блядивый ('празднословный') та же блядь закономерно осталась в качестве этимологически связанного слова (Фасмер 1964, I: 177, 180).

Родственное слову блядь существительное вь́блядок ('незаконнорожденный'), которое используется в качестве юридического термина в Соборном уложении 1649 года (гл. Х, ст. 280), даже во второй половине

15 ДБГ, № 531, http://gramoty.ru/birchbark/document/show/novgorod/531/; Янин, Зализняк, Гиппиус 2015: 247-250. См. там же о былинной формуле курва-блядь. 
XIX столетия воспринималось «без какого-либо оттенка непристойности» (Цявловский 2002: 226). Оно употребляется как нейтральное или по крайней мере приемлемо-грубоватое в дневниковой и эпистолярной прозе Пушкина, Тургенева и Льва Толстого и даже попадает в печать - не только в дореволюционных, но и в советских изданиях.

Матерный пул одновременно пополняется и оскудевает. Из современного употребления (по крайней мере, активного) выпали слова хуерь́к (вариант: хуери́к, 'гонорея') $)^{16}$, елда́ и елда́к ('мужской половой орган') '17, манда́ и шахна́ ('женский половой орган') ${ }^{18}$, се́киль (вариант: си́кель, '1. вульва; 2. клитор') 19 , муде́ ('тестикулы') и некоторые другие.

Слово хуерьі́к присутствует уже в рукописном врачебнике XVII в. (Змеев 1895: 192) ${ }^{20}$ и в Вейсмановом немецко-русско-латинском лексиконе 1731 г., где «гонорея (хуерыкъ болъзнь)» служит аналогом нем. Saamenfluß и греко-лат. gonorhoea (Вейсман 1731: 515; оба иностранных слова буквально означают 'семяистечение'). В такой же форме (с твердым [p]) интересующее нас слово употребляется в Девичьей игрушке (корпус рукописной «барковщины» второй половины XVIII в.; см. Барков и др. 1992: 55, 58, 113-115 и др.). У Пушкина оно встречается только в варианте хуерикъ (Пушкин 1906, I: 11, 84, 259)21, который затем фиксируется в бодуэновском издании словаря Даля (Даль, Бодуэн-де-Куртенэ 1909, IV: 1244)22.

16 О его вероятном происхождении см. Киреев, Сапогов (в печати).

17 Возможно, единственное заимствование в старом матерном пуле (из перс. yaldā, см. Minorsky 1945: 571; Jakobson 1952: 389; Фасмер 1967, II: 13, дополнение О. Н. Трубачева) если, конечно, это действительно персидское заимствование, в чем высказывались обоснованные сомнения (Lunt 1977: 176, note 9; подробнее см. Пильщиков, Иоффе 2021: экскурс 2).

18 См. о них: Пильщиков, Иоффе 2021: экскурс 1 и 3.

19 В форме «ськыл>ь >»» встречается уже в грамоте № 955 (вторая половина XII века), где выступает в составе обсценного сочетания-гендиадиса «пизда и съькыле»; корень тот же, что в глаголах со значением мочеиспускания (сьи́ати, си́кать). См.: ДБГ, № 955, http:// gramoty.ru/birchbark/document/show/novgorod/955/; Зализняк, Янин 2006: 8, 11.

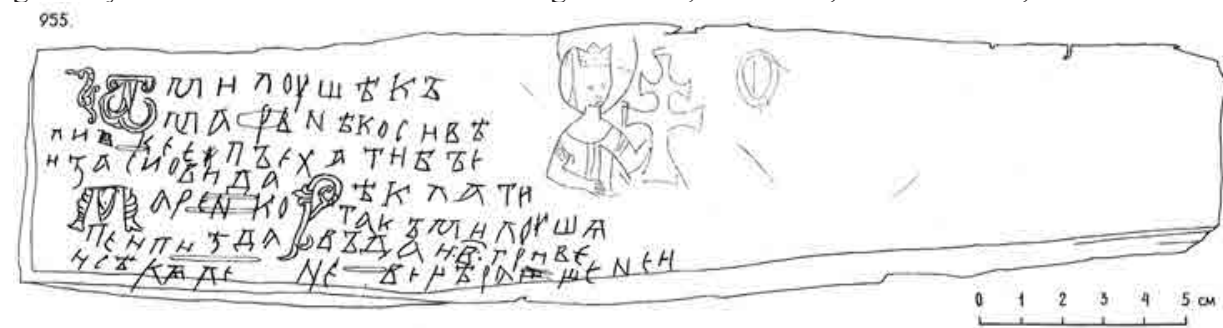

20 Рукопись: ОР РГБ, ф. 310 (Собрание рукописных книг В. М. Ундольского), № 1023, л. 56. Электронная копия: https://lib-fond.ru/lib-rgb/310/f-310-1023\#image-60. В рукописи написание «хуярык[ъ]»; ср. там же: «болњзнь хуярычна^».

21 Особенно примечательно сравнение в письме П. А. Вяземскому от 10 августа 1825 г.: «Какова наша текучая <т. е. 'текущая'. - И. П.> словесность? настоящій хуерикъ!» (259).

22 В первых двух изданиях словаря Даля матерных слов не было, но когда этот словарь вышел в 1903-1909 годах под редакцией великого польско-российского лингвиста Яна Бодуэна-де-Куртенэ, то в своем издании Бодуэн добавил матерные слова (как и другие дополнения, в редакторских скобках) и в послесловии к последнему тому посвятил целую страницу красноречивому обоснованию этого решения (Бодуэн-де-Куртенэ 1909: VI). Сей- 
Форма муде́ (др.-рус. и ц.-сл. мжды) - это глубокая архаика: двойственное число (dualis) существительного мудó (Vasmer 1955, II: 169; Фасмер 1967, II: 669). В древнерусском языке такая форма употреблялась для обозначения двух предметов, а впоследствии утратилась (ее реликты наблюдаются в современном склонении существительных, обозначающих парные предметы). Множественное число того же существительного: муда́, мyдb́, $м y ́ d b l$ и мýdu (всё это - вторичные диалектные варианты). Слово мудо (из *modo, с $o$ носовым) общеславянское, но поиски его индоевропейских параллелей затруднены (ЭССЯ 1994, 20: 123-125).

Хотя само обсуждаемое здесь слово вышло из употребления, сложные слова с корнем муд- (мудозвон, мудоёб) по-прежнему в ходу. Кроме того, широко циркулируют слова муда́к и муди́ло (муди́ла), по поводу которых в ответ на запрос главного редактора Новой газеты от 6 июля 2017 г. было получено специальное разъяснение главы Роскомнадзора А. А. Жарова (от 17 июля 2017 г.), что они «относятся к бранным, [но] не являются нецензурными» (Муратов 2017: 21)23.

Здесь возникает вопрос: связано ли этимологически слово мудак с муде? По всей видимости, да, но, в отличие от мудозвона и мудоёба, не напрямую. В русском языке есть два омонима («мудак1» и «мудак2») с двумя исторически разными корнями ${ }^{24}$. С одной стороны, в западнославянских языках сохранилось слово mudak с исходным *е в корне и значением 'животное с большой мошонкой' (ЭССЯ 1994, 20: 122), и аналогичное слово муда́к в значении ‘баран-производитель’ засвидетельствовано в псковских говоpax (ПОС 2008: 34). С другой стороны, имеется общеславянский корень *mud- с исходным *u и значением 'медлительности' (ст.-сл. и др.-рус. моудити 'медлить' и его производные - см. ЭССЯ 1994, 20: 167-170; Срезневский 1902, II: 185), впоследствии вытесненный в русском языке формой*mъd-(ъ)l- (ц.-сл. мъд(ь)лити, др.-рус. мьдьлити, рус. медлить), связанной с ним закономерным чередованием гласных (ЭССЯ 1994, 20: 206-211; Фасмер 1967, II: 590). От старого и диалектного 25 глагола мудить (с исходным *u, a не *q) вполне допустимо образование отглагольных существительных на -ило/-ила (муди́ло/муди́ла) по модели «чуди́ть $\rightarrow$ чуди́ло/ чуди́ла; дури́ть 'совершать глупости' $\rightarrow$ дури́ло/дури́ла» и аналогическое образование на -ак (муда́к) по модели «чудить//чудак, дурить// дурак». Эту же семантику медленного, долго продолжающегося и неумелого действия имеет глагол того же корня мудо́хаться и отглагольные существительные мудо́ха

час в магазинах продаются репринтные издания словаря Даля, сделанные и со второго, «безматерного» издания, и с третьего, «матерного».

23 В сетевой версии газеты имеется подзаголовок: Переписка Дмитрия Муратова с Роскомнадзором по поводу слова «мудило». https://www.novayagazeta.ru/articles/2017/ 07/20/73184-yavlenie-est-i-slovo-est

24 Гипотеза, высказанная А. В. Дыбо и Д. В. Сичинавой (дискуссия в Facebook, 01.10.2016, режим friends only). https://www.facebook.com/igor.pilshchikov/posts/ 10154095910586028

25 См. ПОС 2008: 34-35. 
и мудо́хала: «Э́та тако́й ниизваро́тливый чилаве́к, мы яво́ завём мудо́хай» (ПОС 2008: 35).

Таким образом, современные русские слова мудак и мудило возникли в результате контаминации. У них, если можно так выразиться, «бастардное» происхождение: частично матерное, частично не матерное, так как их связь с корнем, обозначающем тестикулы, представляет собой не научную, a «народную» этимологию (Volksetymologie) ${ }^{26}$. Поскольку в результате пейоративным оказалось слово с «невинным» корнем *mud-, а нейтральным слово с обсценным корнем *mod-, можно считать, что корень -мyд- со значением 'медлительности' унаследовал пейоративную коннотацию от своего омонима ${ }^{27}$.

По наблюдению Д. В. Сичинавы, слова мудак и мудило (в отличие от муде) «неизвестны в источниках до революции <..> и, по-видимому, были достоянием немногих диалектов, а затем хлынули в город и получили там популярность ${ }^{28}$. Это наблюдение можно уточнить, указав, что первое из этих слов попало в общую речь не из регионального, а из социального диалекта. Слово мудак в значении 'мужик' включено в словарик из собрания В. И. Даля «Условный язык петербургских мошенников, известный под именем музыки или байкового языка» (Даль 1990: 134; Бондалетов 2004: 152, 160; Приёмышева 2009, I: 117; 2: 39, 425). Составлен он был, по-видимому, в 1842 году и переписан для Даля в начале 1850-х (Даль 1990: 133 [вступ. статья А. Л. Топоркова]; Бондалетов 2004: 145-147, 151; Приёмышева 2009, I: 116-129). К тому же источнику восходит словарь, переписанный в 1860-е годы для начальника сыскной полиции Санкт-Петербурга И. Д. Путилина и опубликованный в 1904 году в составе его Записок. В этой версии словаря петербургских «мазуриков» также зафиксировано слово мудак с тем же определением значения (Путилин 1904: 263). Был еще один условный язык, более архаичный и существенно повлиявший на все прочие, офенский (арго коробейников XVIII-XIX веков). По данным офенских словарей, составленных А. А. Успенским (1820), И. И. Срезневским (1839) и Далем (1854), у офеней было другое слово для обозначения «мужика, крестьянина», — «лох» (Успенский 1820: 239-242; Бондалетов 2004: 282, 386; Приёмышева 2007: 339, 341, 349, 358) ${ }^{29}$. То есть изначально «мудак» — это

26 Явление, хорошо иллюстрируемое речью персонажей и сказового повествователя лесковского «Левши», которые говорят «мелкоскоп» вместо микроскоп и «верояция» вместо вариация.

27 В примерах из Псковского областного словаря видно, что омоним с «техническим» значением ('баран-производитель') никак семантически не коррелирует с бранным омонимом, и только бранный омоним синонимичен отглагольному существительному мудила.

28 См. ссылку выше, в примеч. 24.

29 Сводные данные по ряду словарей см. Приёмышева 2009, II: s. v. «лох», «крестьянин», «мужик», «человек». Пример офенской речи («лохи биряли колыги и гомза» и т. д.) см.: Даль 1852: 59 (перепечатано в первом томе «Толкового словаря»: Даль 1863, I: XLVIII). Ср. также: «Лохъ $n c \kappa<$ овское>> <..> розиня, шалапай (на офенскомъ: мужикъ, крестьянинъ вобще)» (Даль 1865, II: 870). К этимологии лоха см. ЭССЯ 1990, 16: 94. 
то же, что и «лох»: «мужик», не принадлежащий миру «наших», объект криминальной или торговой манипуляции. Лексикон старых тайных языков был в значительной степени унаследован общеуголовным арго ХХ столетия (Грачев 2013: 67); в словаре «блатной музыки», изданном для внутреннего пользования НКВД в 1927 году, фигурируют оба слова: «Лох <...> мужик , которого можно одурачить»; «Мудак - мужик; человек не бывавший в тюрьме, дурак» (Потапов 1927: 84, 94) ${ }^{30}$. Вскоре слово мудак проникло в общерусское просторечие ${ }^{31}$. Произошло это после первой волны массового попадания разных слоев населения в лагеря и прямого контакта цивильных с уголовным миром - в конце 1930-х годов: «старшие известные нам письменные свидетельства существования этого слова есть в двух синхронных советских дневниках 1940 года» ${ }^{32}$. То же самое произошло со словом лох, но гораздо позже, в период резкой криминализации русского просторечия, пришедшейся на первое постсоветское десятилетие ${ }^{33}$.

От собственно матерной лексики следует отличать также заимствованные обсценные, но не табуированные слова (такие, как пута́на), вульгаризированные медицинские и прочие термины типа гондо́н (из кондо́м) или пидора́c (из педера́cm) и вульгарно-просторечные (но тоже не табуированные, хотя и ограниченные к употреблению неформальными контекстами) слова и выражения типа жопа, сукин сын и т. п.

В вульгарной латыни и в новых романских языках путана - обсценное слово, а проститутка - его нейтральный эвфемизм (Adams 1983: 344, $358)^{34}$. В современном русском языке, скорее, путана - эвфемизм проститутки (ср. Горбачевич 1996: 320-321). Сегодняшние читатели удивятся, узнав, что слово гондон включено в советский нормативный словарь рус-

30 Ср. здесь же «Мудило - бесполезный» [т. е. бесполезный, никчемный человек] (Потапов 1927: 94).

31 Процесс, захвативший и другие криминальные арготизмы (Приёмышева 2009, I: 394-397). Характерно при этом, что обычно «в просторечие переходит только та лексика, которая теряет свою употребительность и актуальность в воровской речи» (Там же: 394).

32 Д. В. Сичинава, email от 04.04.2021, где приведены и упомянутые примеры. Геолог Борис Вронский (1898-1980), запись 25 июля 1940 г.: «Коснемся немного филологии. Среди прочих ядовитых и метких словечек, которыми так богат русский язык, есть одно слово, в литературе не употребляемое, хотя по своей насыщенности и значимости оно вполне заслуживает этого. Слово это - “мудак”. В переводе на обычный житейский жаргон это нечто аналогичное слову “шляпа", но только более подчеркнутое, вроде как-бы шляпы, надеваемой на нецензурное место. Так вот, сегодня я пришел к глубокому убеждению, что дядя Андрео <sic!> - типичнейший стопроцентный мудак» («Прожито». https://prozhito. org/note/565193). Журналист Лазарь Бронтман (1905-1953) в записи от 25 декабря 1940 г. цитирует свою реплику в разговоре этого дня с летчиком Владимиром Коккинакки (19041985) и ответ последнего: «Когда ты пишешь о своем первом полете, окончившемся аварией, читатель просто посмеется, т. к. он знает, кто ты сейчас. Но если ты напишешь аварию незнакомого читателю летчика, он, читатель, прочтет и скажет: чего таких мудаков пускают в авиацию? - А ведь ты прав. Я этого и не сообразил. Вообще мне много сейчас стало яснее» («Прожито». https://prozhito.org/note/6037).

33 См. полезную статью Т. М. Веселовской «Кто такие лохи?» (2001), где, однако, отсутствуют сведения, которые можно почерпнуть из ЭССЯ и офенских словарей.

34 Этимологически puttana означает 'девка' (от вульг. лат. putta 'девушка'). 
ского языка под редакцией Д. Н. Ушакова как допустимое «разг<оворное>» (Ушаков 1935, I: 595, 1435). «"Неприличие” - категория историческая», заметил пушкинист М. А. Цявловский (2002: 226), комментируя сквернословие классика.

\section{5. Матерились ли классики?}

Читателей обычно интригует использование мата русскими классиками. Интересно, зачем; интересно, почему; интересно, что это для них значило.

Для Пушкина, особенно раннего, обращение к мату в литературе было связано с традицией XVIII века. Эстетическая система классицизма разделяла все литературные жанры на высокие, средние и низкие. В низких жанрах с языком позволялось делать то, что категорически запрещалось в высоких жанрах: в произведения низких жанров можно было вводить просторечие и достаточно грубую, но не матерную брань. Кроме того, появилась рукописная литература, связанная с именем Ивана Баркова, которая пародировала жанры официальной литературы с помощью матерной лексики.

Механизм такой пародии, общий для русской и западноевропейской литературы, - это бурлескная травестия произведений высоких жанров. Классический бурлеск берет образцовый сюжет - например, Вергилиеву Энеиду - и пересказывает ее низким языком, вводя, кроме того, в текст комические мотивы, связанные с пьянством, драками и беспорядочными сексуальными связями. Первым такое произведение написал в середине XVII века Поль Скаррон. Оно озаглавлено Травестированный [то есть nереодетьй] Вергилий (Virgile travesti) или, полностью, Вергилий, переодетый в бурлескные стихи (Virgile travesti en vers burlesques).

«Обычный» бурлеск может развиться в бурлеск обсценный, в котором место грубо-просторечных слов занимает вульгарное просторечие и вульгарная обсценная лексика. Это не специфично русское явление; более того, оно заимствовано русской литературой из французской. Самым знаменитым произведением такого рода во французской литературе была «Ода Приапу» Алексиса Пирона, написанная в начале XVIII века и ставшая одним из жанровых образцов для Баркова и его последователей, которые пародировали все жанры русского классицизма: оды, трагедии, элегии, надписи, притчи и далее по списку (Шапир 2002). В конце XVIII века эти произведения были объединены в рукописный сборник, озаглавленный Девичья игрушка (см. Барков и др. 1992).

В России такая литературная игра получила еще большее значение, чем во Франции. Из-за употребления мата она стала полностью непечатной, но при этом хорошо укладывалась в сетку классицистских жанров, будучи их зеркальным отражением. Цель кривого зеркала - не высмеять того, кто в него смотрится, а просто повеселиться, насладившись искажением знакомого и любимого облика (Морозов 1960: 17-24; Пильщиков 
2007). Обсценный бурлеск в максимальной степени эксплуатирует главные свойства матерной лексики и фразеологии - ее вульгарность и экспрессивность. Впрочем, удельный вес собственно матерных слов в барковщине не так уж велик - всего 1,5-2\%. Но на фоне высоких подлинников звучат они настолько «ударно», что текст воспринимается как чистое и беспримесное сквернословие.

Пушкин с удовольствием читал барковщину. Как известно, он сказал юному сыну своего друга князя Вяземского, что «первые книги, которые выйдут в России без цензуры, будет полное собрание стихотворений Баркова» (ПВС 1998, II: 180) — что, собственно, и произошло в 1992 году. Барков стал символом русской поэтической похабщины. Тот же Пушкин писал старшему Вяземскому 10 июля 1826 г.: «Всњ возмутительныя рукописи ходили подъ моимъ именемъ какъ всь похабныя ходятъ подъ именемъ Баркова» (Пушкин 1906, I: 358). Действительно, и в допушкинское, и в послепушкинское время переписчики приписывали Баркову все непристойные произведения, в том числе те, что были, несомненно, написаны во второй половине XIX века - например, поэму Лука Мудищев (Taranovsky 1982: 429-432; Шапир 1997: 89, 119).

Сам Пушкин написал в барковском духе раннюю обсценно-порнографическую балладу «Тень Баркова», в которой пародировал стихи Жуковского и Батюшкова, подобно тому, как барковцы пародировали стихи Ломоносова и Сумарокова (Шапир 2000). Это произведение в такой степени насыщено матерной лексикой (матерных слов в нем в 2,5-3 раза больше, чем у самого Баркова) ${ }^{35}$, что некоторые исследователи отказываются верить, что «Тень Баркова» принадлежит Пушкину, — на мой взгляд, безосновательно (Пильщиков, Шапир 2002; 2005; Pilshchikov 2012).

Пушкин легко употреблял матерную лексику и фразеологию в шутливых и пародийных стихотворениях, не предназначенных для печати. B первой четверти XIX века, помимо официальный поэзии, существовала и имела большое культурное значение поэзия домашних кружков и салонов, и она была гораздо свободнее в выборе тем и языка по сравнению с подцензурной литературой (Эйхенбаум 1929). К той же категории относились тексты написанные «в стол», «для себя» - граница между ними и текстами «для друзей» практически неразличима. Вот, например, стихотворение Пушкина «Сводня грустно за столом...» (1827):

Сводня грустно за столом

Карты разлагает.

Смотрят барышни кругом,

Сводня им гадает.

Приходит гость:

Что? Хороший человек...

Сводня с ним знакома,

35 Пильщиков, Шапир 2002: 309. 
Он с блядями целый век,

Он у них, как дома.

Хозяйка жалуется:

«Четверых гостей, гляжу,

Бог мне посылает.

Я блядей им вывожу,

Каждый выбирает.

Занимаются всю ночь,

Кончили, и что же?

Не платя, пошли все прочь,

Господи, мой боже!»

Гость ей:

«Право мне вас жаль.

Здравствуй, друг Анета,

[Что за шляпка!], что за шаль,

Подойди, Жанета.

А, Луиза, - поцалуй,

Выбрать, так обидишь;

Так на всех и встанет хуй,

Только вас увидишь».

Гость, однако, никого не выбрав, уходит:

Сводня карты вновь берет,

Молча вновь гадает,

Но никто, никто нейдет -

Сводня засыпает ${ }^{36}$.

Стихотворение имеет реальную подоплеку. По-видимому, оно посвящено Софье Астафьевне (Евстафьевне) - содержательнице известного в то время петербургского борделя. Друзья поэта вспоминали «о прежних прогулках с Пушкиным-холостяком; как они, бывало, заходили к наипочтеннейшей Софье Евстафьевне провести остаток ночи с ее компаньонками» (Губер 1923: 31-34; Черейский 1989: 415). «Сводня» в этом и других текстах Пушкина имеет не то же самое значение, в котором мы употребляем это слово сегодня ('корыстная посредница между частными лицами, способствующая вступлению их в сексуальную связь'), — в пушкинское время термин «сводня» был более профессионально-техническим, обозначая содержательницу и распорядительницу публичного дома.

Поход в публичный дом - вполне обычное времяпрепровождение для холостого дворянина в XIX столетии. Лев Толстой устами героя «Крейцеровой сонаты» вспоминает об этом обычае с гневом и омерзением,

36 Пушкин 1948, III.1: 77-79. Купюры академического издания восстановлены здесь по факсимиле автографа (ПД № 836, л. 26-26об.), воспроизведенному в кн.: Пушкин 1996. Сам факт купирования текстов в сугубо научном издании ставит большое академическое собрание Пушкина в один ряд социокультурных явлений с советским изданием словаря Фасмера (Зорин 1996: 129-130). 
но Пушкин и его друзья, судя по всему, не находили это предосудительным. В сборнике «анекдотов» (примечательных событий), озаглавленном «Table-talk», Пушкин записал: «Дельвиг звал однажды Рылеева к девкам. “Я женат”, отвечал Рылеев. - “Так что же, сказал Дельвиг, разве ты не можешь отобедать в ресторации, потому только, что у тебя дома есть кухня?"》 (Пушкин 1949, XII: 159).

Обитательницы борделя упоминаются в целом ряде непечатных стихотворений Пушкина - иногда со смехом, иногда с грустью, но всегда без осуждения. В послании к Дельвигу («Друг Дельвиг, мой парнасский брат...», 1821) Пушкин сравнивает со сводней самого себя:
К неверной славе я хладею;
И по привычке лишь одной
Лениво волочусь за нею,
Как муж за гордою женой.
Я позабыл ее обеты,
Одна свобода мой кумир,
Но все люблю, мои поэты,
Счастливый голос ваших лир.
Так точно, позабыв сегодня
Проказы младости своей,
Глядит с улыбкой ваша сводня
На шашни молодых блядей.

(Пушкин 2016: 23)

Поход в бордель описан в главном произведении родного дяди Пушкина Василия Львовича - ирои-комической поэме Опасный сосед (1811). Как и бурлеск, ирои-комика строится на несовпадении тематики и стилистики, но если бурлеск соединяет высокую тематику с низким стилем, то ирои-комика, наоборот, совмещает низкую тематику (бордель, пьянство, драка) и высокий стиль. Ирои-комика тоже травестирует высокую героическую поэзию, и низкие темы в ней не только дозволены, но и обязательны - для контраста с пародируемыми эпопеями. Пушкин любил дядино произведение и неоднократно цитировал его в стихах и в письмах, а главного героя Опасного соседа Буянова назвал в пятой главе Евгения Онегина своим двоюродным братом (как если бы «родителем» Буянова был сам Василий Львович). Четыре гостя, о которых сводня в стихотворении поэтаплемянника рассказывает, что они «не платя, пошли все прочь», — это герои Опасного соседа: рассказчик, Буянов, купец и дьячок (Михайлова 2004: 198).

«Сводня...» тоже содержит в себе элемент травестии - Пушкин пародирует балладу Жуковского «Светлана», написанную тем же размером Х4343мжмж (разностопный хорей, в котором чередуются четырехстопные строки с мужским окончанием и трехстопные с женским):

Раз в крещенский вечерок Девушки гадали: 
За ворота башмачок,

Сняв с ноги, бросали $<\ldots>37$

Сам Пушкин не противопоставлял свои серьезные и шуточные произведения столь же строго, как того хотелось бы блюстителям пушкинской нравственности. Для написания «Сводни...» он отвлекся от работы над седьмой главой Онегина и записал шуточное стихотворение на тех же листах рабочей тетради, в которой работал над «романом в стихах» (Иезуитова 1991: 127). Три года спустя Пушкин добавил (нематерную) строфу к стихотворению Дениса Давыдова «Герою битв, биваков, трактиров и блядей», где также фигурируют сводня и бордель, а бляди, помимо заголовка, появляются в ударной рифменной позиции в заключительном стихе. Стихотворение это, наряду с другими сочинениями «лихого гусарского пошиба», было напечатано в сборнике стихов Давыдова 1832 года с заменой фривольных слов точками (Лернер 1923: 21-22; Пушкин 1949, III.2: 1288-1289).

Один из важнейших элементов стилистической программы Пушкина - повышение стилистического разнообразия. Поэт стремился максимально расширить экспрессивный диапазон литературного языка и даже считал возможным выходить за его пределы. В «народной трагедии» Борис Годунов сталкиваются языковые стихии, не совместимые с точки зрения эстетики классицизма, дозволявшей смешение высокого и низкого только в комических жанрах. С одной стороны, это стихия высокой поэзии: торжественные церковнославянизмы, вкрапления старорусских летописных оборотов. С другой стороны, это низкая прозаическая стихия - бытовое просторечие и даже вульгарная лексика (Винокур 1959: 304-312). Пушкин писал друзьям: «Въ моемъ <">Борись <"> бранятся по матерну на всьхъ языкахъ. Это трагедія не для прекраснаго полу» (Пушкин 1906, I: 334). В Годунове и по-русски, и по-французски говорят очень грубо, причем в черновых вариантах грубее, чем в печатной редакции. В печатном тексте пьяный монах Варлаам говорит: «Отстаньте, пострьлы!»; сейчас печатают по рукописи: «Отстаньте, сукины дьти!» — но в первоначальном варианте у Пушкина было еще грубее: «Отстаньте, блядины дьти» (Пушкин 1831: 43; 2009: 34, 282, 376, 380). Это выражение, неоднократно встречающееся, например, у протопопа Аввакума (см. Аввакум 1934: 216, 226, 234, 241, 251, 272, 313, 334, 355; ср. Гудзий 1934: 35-36; Юрганов 2000), по всей видимости, попало к Пушкину из летописной цитаты у Карамзина (Винокур 1935: 472).

Пушкин использовал грубую матерную лексику в письмах, но далеко не всегда. С некоторыми своими друзьями - например, с Вяземским и Соболевским - Пушкин употреблял матерные выражения достаточно регулярно, а в переписке с другими адресатами выбирал иные стилистические регистры. Иногда это объясняют каким-то особым цинизмом Соболевского и Вяземского, чьей манере Пушкин отчасти подражал в ответных письмах (Цявловский 2002: 232), но здесь, скорее, нужно обратить внимание

37 См. Михайлова 2004: 200-201. 
на другое. В общении со своими близкими Пушкин часто экспериментирует с языком, и грубые выражения употребляет не только в письмах к своим закадычным друзьям, но и к собственной жене - правда, в письмах к жене он использует выражения нарочито грубые, но не матерные.

Со своей невестой Natalie Гончаровой Пушкин переписывался исключительно по-французски (Паперно 1975: 152) ${ }^{38}$, но когда она стала его женой, перешел в переписке на русский. Язык этой переписки намеренно сниженный. Пушкин моделирует ситуацию семьянина, главы дома, который говорит с женой простой русской речью. Ему нравятся слова типа жёнка, брюхата (в значении 'беременна') и т. п. (Лотман 1981: 201-204). Огрубление речи до просторечия в письмах жене и огрубление речи до мата в письмах Соболевскому и Вяземскому — это явления одного стилистического ряда.

Пушкин экспериментировал с матом не только в домашней поэзии и в частной переписке. Помимо попыток огрубить текст Бориса Годунова, потрясающим примером пушкинского эксперимента с нарушением границы между табуированным и нетабуированным является стихотворение «Телега жизни» (1823). Это философская притча на традиционную тему об эпохах человеческой жизни (детство - средний возраст — старость). Вот две первые строфы:

Хоть тяжело подъ часъ въ ней бремя,
Телега на ходу легка;
Ямщик лихой, съдое время,
Везетъ, не слезетъ съ облучка.
Съ утра садимся мы въ телегу;
Мы рады голову сломать
И, презирая льнь и нъгу,
Кричимъ: пошоль! .....

(Пушкин 1829: 180)

В пушкинском стихотворении, по словам компетентного историка русского литературного языка В. В. Виноградова, «остро врезываются в повествовательное построение простонародно-бытовые, далекие от стеснительных норм салонной вежливости грубые окрики путника на ямщика» и в результате «происходит резкое преобразование литературной <... символики, связанной с образом времени» (Виноградов 1935: 441, 439).

«Ебёна мать» рано начинает употребляться как чистый экскламатив с контекстуально обусловленным значением и в результате быстро приобретает многозначность. Этому явлению специально посвящено непечатное «Рондо на Ебену мать» - стихотворение конца XVIII века, примыкающее к более раннему основному корпусу Девичьей игрушки:

38 Единственное исключение - письмо, посланное из Болдина около 29 октября 1830 г., которое начинается словами: «Милостивая государыня, Наталья Николаевна, я пофранцузски браниться не умею, так позвольте мне говорить вам по-русски, а вы, мой ангел, отвечайте мне хоть по-чухонски, да только отвечайте» (Пушкин 1986: 16). 
Ебена мать ту тварь ебену означает,

Из бездны коея людей хуй извлекает.

Вот тесный смысл сих слов; но смысл пространный знать

Не может о себе сама ебена мать!

Ебена мать в своем лишь смысле не кладется,

А в образе чужом повсюду кстати гнется.

Под иероглиф сей все можно пригибать,

Синонима есть всем словам ебена мать.

$<\ldots>$

Ебена мать кладут и в знак местоименья

К таким, которые у нас без уваженья:

Коль хочешь, например, ты имрака назвать,

Вот так его зови: ей ты!! ебена мать!!!

Ебена мать уж mbl! - значит к тебе презренье,

Уж я ебена мать - значит к себе почтенье,

Что за ебена мать? - есть недоумевать,

А храбрости есть знак: кто нас! ебена мать! 39

Но одно дело «знак храбрости» в нецензурной, а другое — в печатной словесности. Принято считать, что сквернословие в русской классической литературе «было жестко запрещено как безусловное нарушение конвенциональной этической и эстетической нормы. Поэтому узнать, что едва ли не все великие русские писатели были в быту изрядными матерщинниками, пытливый старшеклассник мог лишь из их дневников, писем, стихов на случай и для узкого круга посвященных, но никак не из текстов, предназначавшихся для печати» (Чупринин 2004: 148). Как видим, это не так или не совсем так. Нарушитель установленного порядка - Пушкин.

Печатая «Телегу жизни» в собрании своих стихотворений, Пушкин заменил отточием «русский титул» (как он сам назвал оборот ебёна мать, посылая это произведение Вяземскому 29 ноября 1824 г.) $)^{40}$. Но поскольку ебёна мать находится в рифме, то продекламировать «Телегу жизни», не произнеся «русский титул», невозможно. Таким образом, Пушкин употребил мат в произведении не только предназначенном для печати, но и реально напечатанном. Этот пример можно считать образцовым применением мата в литературе: экспрессивная функция мата и его связь с разговорным народным началом использованы поэтом в полной мере. Полтора века спустя пушкинским приемом воспользовался Иосиф Бродский в стихотворении «Натюрморт» (1971), развивающем философскую тематику английской метафизической поэзии:

Вещь есть пространство, вне коего вещи нет.

39 Барков и др. 1992: 260. Заглавия в других списках — «Ебена мать» и «Рондо» (Там же: 396).

40 В письме обсуждаемая строка читается «Кричимъ: валяй, ебена мать!». «Можно напечатать, пропустивъ русскій титулъ», — заключает автор (Пушкин 1906, I: 151-152). 


\begin{abstract}
Вещь можно грохнуть, сжечь, распотрошить, сломать. Бросить. При этом вещь не крикнет: «Ебёна мать!»
\end{abstract}

(Бродский 1977: 111)

Что же касается домашней, кружковой словесности, то такого рода литература «для своих», в том числе и грубо-сексуально-комическая, существовала и в послепушкинскую эпоху, в 50-60-е годы XIX века. Поэзия «не для дам», продолжающая обсценную шутливую поэзию пушкинского круга, практиковалась в кружке Лонгинова - Дружинина, куда входили Тургенев и Некрасов (Ранчин, Сапов 1994; Трунин 2017). Примечательно, что среди участников этого кружка было несколько литераторов из числа тех, кого принято называть «первыми пушкинистами»: М. Н. Лонгинов один из первых русских библиографов и исследователей пушкинской эпохи, А. В. Дружинин - один из самых тонких критиков поэзии предыдущего поколения. Вполне возможно, что они ориентировались на «домашнюю» культуру предыдущей эпохи и тем самым выпадали из контекста новых десятилетий.

В конце XIX века интерес к обсценной поэзии практически сошел на нет. Чисто эстетического удовольствия она уже не доставляла (никто не помнил и не угадывал объекты пародии), любители «клубнички» переключились на порнографию (расцвет которой пришелся на вторую половину XIX и начало XX века), а модернистская эротика развивалась по совсем другим законам (редким исключением стали Занавешенные картинки М. Кузмина, стилизованные под старинуㄹ).

Перечислим основные этапы развития «матерной» литературы в XVIIIXXI веках: барковщина в XVIII веке; использование ее механизмов для создания «домашней» литературы в начале XIX века; пушкинские эксперименты с вводом элементов матерной лексики и фразеологии в печатную литературу - очень смелые и не имеющие аналогов в литературе того времени; и, наконец, домашняя литература авторов послепушкинского периода, которая уже не находит продолжения у писателей второй половины XIX века. Вновь интерес к мату возникает в литературе и культуре второй половины XX столетия - от Александра Солженицына до Юза Алешковского, от Иосифа Бродского до Сергея Шнурова и от Алексея Германа до Кирилла Серебренникова.

Во второй половине XX века мат окончательно вырывается из-под спуда социальных запретов и занимает исключительное место в устной

41 См. в особенности два заключительных стихотворения цикла - «Размышления Луки» (1918) и «Начало повести» (1914). Последнее стихотворение, содержащее незавуалированный мат (блядь, еблась, ебня) имеет в автографе подзаголовок «(d'après Барков)», хотя стилизовано оно не под подлинного Баркова, а под псевдобарковщину XIX столетия, самым известным примером которой можно считать анонимную поэму Лука Мудищев (ср. Богомолов 1996: 738). 
речи практических всех социальных групп современного русского общества ${ }^{42}$. Характерно, что у Бродского, который в высокой лирике шокировал читателя единичными обсцентизмами, в дружеских - первоначально не предназначавшихся для публикации - стихотворных посланиях к Виктору Голышеву $(1971,1974,1977)$ вульгаризмы разливаются вольной стихией, не сдерживаемой никакими стилистическими ограничениями. Вот строки из послания, написанного одновременно с «Натюрмортом»:

...Но бздя, чтоб названное Зло, в прекрасном с сотворенья света рассеянное всюду, это прекрасное переросло, дает нам Время некий срок; и к их ебальникам и к речи привык я и расправил плечи. «Бессмертья, может быть, залог».

А сам Дом Творчества - говно.

Похож на полусинагогуполуобщагу. Харч изжогу обычно вызывает; но харч в регулярные часы, и можно вкалывать не хуже, чем дома. Вечером снаружи транзисторы вопят и псы.

В сортире плавает гондон; Но вообще-то дом пустует. Одни вахтеры, и бюстует средь холла с фикусом Антон

П. Чехов. Я перевожу и сочиняю. Впрочем, редко. Приняв снотворную таблетку, я сплю, не слыша, как пержу.

Говно, конечно. И спустить, конечно, некуда... И все же всю эту поебень и рожи я, кажется, готов простить за то,............. etc. etc. etc.

(Бродский 1996: 62-63) 43

42 По состоянию на 2000 год, «согласно данным ВЦИОМ, ежедневно пользуются грубыми ругательствами $25 \%$ женского населения России, $44 \%$ руководящего состава, $50 \%$ рабочих и $54 \%$ безработных», в целом же «матерятся $70 \%$ россиян, причем ни образование, ни место жительства особой роли не играют» (Жельвис 2001: 44, 65).

43 Несколько скромнее звучит позднейшее послание к тому же адресату (1995), которое было опубликовано в Новой газете (2000) без купюр, несмотря на обилие вульга- 


\section{6. Русский мат: вчера, сегодня, завтра}

Итак, со временем способы и цели употребления мата меняются, поэтому нельзя сказать, что якобы «в XVI-XVII вв. он существовал в том самом виде, в каком существует сейчас» (Жельвис 2001: 14). Не только в Древней Руси он был совсем не таким, как сейчас, но и в пушкинское время он был не совсем таким, как сейчас. Главное отличие заключается в том, что вплоть до конца XIX века матерные слова употреблялись преимущественно в прямом значении, а количество слов, образованных с помощью базовых корней, было ограниченным. Сейчас дело обстоит совсем иначе (Пильщиков 2022).

Во-первых, матерные корни стали принимать почти любое переносное значение, то есть обозначать практически все, что угодно. Во-вторых, матерных слов и выражений стало много. Произошел «деривационный взрыв»: появилась возможность образовывать матерные окказионализмы (слова, образованные hic et nunc и понятные носителям языка, поскольку подчиняются усвоенным языковым правилам). Некоторые из этих слов стали общераспространенными, и в результате за относительно короткое время в языке появилось необычайно много новых матерных слов, образующих устойчивые и окказиональные сочетания. Эти явления были описаны в статье Ф. Дрейзина и Т. Пристли «Систематический подход к русскому обсценному языку» (Dreizin, Priestly 1982) и в статье Ю. И. Левина «Об обсценных выражениях русского языка» (Левин 1986).

Первое из упомянутых явлений лингвисты назвали «прономинализацией»: матерные слова «про-номинализируются» и «про-вербализируются», то есть начинают вести себя как «местоимения» («PRO-nouns») и «местоглаголия» («PRO-verbs») (Dreizin, Priestly 1982: 234; Timroth 1983: 151-155; Левин 1986: 67-68). Значение слов типа хуйня́, хуеплёт, хуйну́ть, хуя́чить, захуя́чить, расхуя́чить и т. д. полностью определяется смысловым контекстом и синтаксическими связями (Dreizin, Priestly 1982: 239-240). Подобным же образом ведут себя местоимения: слово «он» обозначает разных людей в зависимости от того, к кому оно применяется. Поэтому можно говорить о местоименной (в широком смысле термина) функции матерных слов. Эту их особенность отметил еще анонимный автор «Рондо на Ебену мать» («Ебена мать кладут и в знак местоименья»). Можно также сказать, что такие слова теряют лексическую семантику, сохраняя лишь грамматическую, которая определяется значением префиксов и суффиксов. Например, слово хуйну́mь имеет грамматическую семантику одноразового действия, а что оно конкретно означает - зависит от семантического и синтаксического контекста: можно «хуйнуть ('пойти, направиться') куда-то», «хуйнуть (‘бросить') что-то куда-то», а можно «хуйнуть ('ударить') кого-то

ризмов (мурло, дерьмо, помацать и др.), эвфемизмов (послать на «Х»- рифма: мха) и одного обсценного (но всё же не матерного, согласно будущему закону) сло́ва: «...переставляя буквы в ДУМЕ, / приятно получать МУДЕ» (Бродский 2000: 23). 
чем-то или чем-то обо что-то». Ср. «захуячить ('засунуть, затерять') что-то куда-то», «захуячить ('стукнуть') кому-то чем-то» и т. д. Генетически прономинализация представляет собой конечную стадию метафоризации: обсценные слова, которые первоначально употреблялись только в прямом (материальном, техническом) значении, начали употребляться в переносном смысле. Эта особенность также не ускользнула от внимания прозорливого автора «Рондо» («Синонима есть всем словам ебена мать»). Обе указанные особенности, свойственные мату XVIII-XIX веков лишь в зачаточной степени, в XX столетии широко распространились и многократно усилились.

Суть второго явления, которое я назвал здесь «деривационным взрывом», состоит в том, что новые матерные слова образуются по десяткам словообразовательных моделей 44 . Один и тот же корень порождает десятки и даже сотни слов с самыми разнообразными буквальными и метафорическими значениями (как устойчивыми, так и окказиональными): въ́ебать, выёбываться, доеба́mь, доеба́ться, доёбываться, ебану́mь, ебану́ться, ёбнуть, ёбнуться, заеба́ться, изъебну́ться, наеба́ть, наебну́ть, наебну́ться, объеба́mь, подъёбывать, подъёбываться, подъебну́ться, перееба́ть, перееба́ться («они там все переебли́сь»), приеба́ть, приеба́ться, приёбьваться, съеба́ть, съеба́ться, съёбьваться, уебну́ть, уеба́ть, уеба́ться, уёбиваться и т. д. (ср. Raskin 1978: 321-325; Dreizin, Priestly 1982: 238; Мокиенко 1994: 61).

Ничего подобного в начале XIX века не было. А. Б. Пеньковский писал: «...тот язык, на котором думал, говорил, писал и творил Пушкин, — это язык, во многом близкий к современному, очень на него похожий, но в то же время глубоко от него отличный» (Пеньковский 2005: 6). Сказанное относится и к матерной идиоматике. В полном списке обсценных слов из пушкинских текстов, составленном М. А. Цявловским (2002: 212-226), все матерные слова употреблены исключительно в прямом значении: «так на всех и встанет хуй» («Сводня грустно за столом...», 1827); «законная пизда род теплой шапки с ушами» (из письма П. А. Вяземскому от 22 мая 1826 г.) и т. п. Единственное метафорическое употребление, трактуемое Цявловским как галлицизм («а ты наебаешься нами» в письме в черновике письма Вяземскому от 4 ноября 1823 г.), сомнительно: черновик в этом месте читается лишь гипотетически (ср. Левичева 2001: 21; автограф: ПД № 834, л. 33). Конечно, многие высказывания небуквальны в том смысле, что не являются призывом к реальному действию: «отослать Толстого к хую» («Язвительный поэт, остряк замысловатый...», 1821, черновая редакция), «и мать его ети» («Веселого пути я Блудову желаю...», 1825) и прочее. Однако само матерное слово используется в этих выражениях в своем буквальном значении.

Пример из послания Пушкина Вяземскому: отослать к ху́ю (рифма: другу́ю) $)^{45}$ — на месте привычного нам послать на́ хуй46 свидетельствует

\footnotetext{
44 Их список и анализ см.: Raskin 1978; Ermen 1993: 22-39.

45 Пушкин 2016: 391.

46 Ср. Василий Буй 2005: 81.
} 
о том, что $x y и ̆$ достаточно рано начинает использоваться как дисфемизм 47 чёрта. Фразеология этих двух слов существенно пересекается. В Пословицах русского народа, собранных В. И. Далем, мы находим следующие фразеологизмы: «На чорта?», «На кой чортъ?», «Чортъ ли въ немъ?», «А чортъ его знаетъ!», «Чорта съ два!», «Убирайся къ чорту!» (Даль 1862: 13). Ср.: на хуя́ и на ко́й ху́ú ('зачем'), ху́й ли (аллегроформа: ху́ли), «а ху́й его зна́ет!», ху́я с два́, отослать/убираться/пойти к ху́ю. Последний оборот встречается в афанасьевских «заветных» сказках наравне с посыланием «к чёрту»: «Какой, ебена мать, медвьдь? Пошоль къ хую, не бредь!» (вариант: «поди къ хую, не бредь»); «Ну, братъ, сльзай съ телеги долой да убирайся отъ грђха къ хую» (Афанасьев 1865/1872: 11-12, 73; 1997: 32, 96) - и сохраняется в народной речи до середины XX века ${ }^{48}$. Выражения «какого чорта» и «какого хуя» также употребляются в «заветных» сказках в как синонимические (Афанасьев 1865/1872: 165; 1997: 192, 432).

Позднейшее посылание на... (а не к...) могло бы объясняться эллипсисом: идти/пойти (к чёрту) на́ хуй (ср. к чёрту на рога). Однако, судя по всему, оно имеет более замысловатый генезис. В Русских заветных пословицах u поговорках, собранных В. И. Далем и переданных им А. Н. Афанасьеву, обстоятельство на́ хуй мотивировано каламбурной рифмой: «Убирайся к монаху — на хуй. (Рифма.)» (Афанасьев 1997: 505). К этой пословице Афанасьев или его сотрудник П. А. Ефремов добавили слышанный им эвфемистический безрифеменный вариант: «Убирайся к мерину на пятую ногу» (Афанасьев 1997: 505; ср. Бессмертных 1997: 581). В тех случаях, когда слово $x y \check{u}$ в «заветной» поговорке употребляется не в материальном значении, оно используется как дисфемизм к местоимению что (подробнее см. ниже, § 7): «Хорош зять, да не́ хуй взять» [не́ хуй = не́чего]; «Не́ хуем петь, когда (коли) голосу нет» [не́ хуем = не́зачем] (Афанасьев 1997: 505, 497; о ритмической и эвфонической структуре поговорки про зятя см. Carey 1972: 97). Условность обсценных инвектив, экспрессивная многозначность и дисфемизация в дальнейшем откроют путь к безграничной метафоризации матерной идиоматики.

Тотальная метафоризация мата — это, несомненно, более позднее явление, но к какому именно времени его следует отнести, пока неясно. Судя по всему, обсуждаемая тенденция проявилась во второй половине XIX столетия и стала доминантной в XX-XXI веках, когда одновременно с увеличением числа матерных слов и выражений сократилось количество матерных корней. В матерном пуле осталось всего четыре корня, но они образуют очень много слов - гораздо больше, чем раньше образовывали все старые корни, вместе взятые. Показательно, что слова, в XX веке выпавшие из ма-

47 Функция, обратная по отношению к эвфемистической (замена приличного неприличным vs. замена неприличного приличным). О дисфемизмах см. Жельвис 2001: 87-88; Ковшова 2007: 105-118; 2019: 40.

48 Ср. слова крестьянина, записанные в дневнике М. М. Пришвина между 1 и 4 ноября 1928 г.: «Ночью стало морозить, на заре озеро замерзло и утки улетели к х<ую>» (Пришвин 2004: 303). 
терного пула или ушедшие на его периферию (елда, шахна и др.), метафоризации не поддаются (Dreizin, Priestly 1982: 237).

Общеизвестен рассказ Достоевского (включенный в цикл Маленькие картинки из Дневника писателя за 1873 год) о том, как несколько «пьяных мастеровых» говорят языком, который «состоит из одного только слова, чрезвычайно удобно произносимого» - «одного нелексиконного существительного», «до крайности к тому же немногосложного», и на все вопросы они отвечают «тем же самым одним заповедным словом, тем же крайне односложным названием одного предмета», меняя лишь интонацию (Достоевский 1980: 108-109) ${ }^{49}$. Анализ этого пассажа в классических работах Бахтина(?)-Волошинова (1930: 105-107) и Выготского (1934: 298-299), написанных шесть десятилетий спустя, подтверждает, что Достоевский описывает интонационное и, вероятно, фразеологическое варьирование

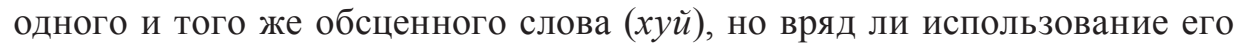
лексических дериватов (вопреки Timroth 1983: 107; Kovalev 2014: 122-123). Однако еще через четыре десятилетия, то есть почти через сто лет после Достоевского выдающийся лингвист А. А. Зализняк засвидетельствовал исключительные словообразовательные возможности, демонстрируемые другим обсценным корнем (еб-). Вот что, по воспоминаниям А. К. Жолковского, произошло в 1969 году:

Неловко разворачиваясь, Андрей [Зализняк] на своем маленьком «Москвиче» чуть не угодил под колеса огромного самосвала, шофер которого высунулся из кабины и заорал... Тут Андрей наигранно осекся и продолжал уже на сдавленном смехе своим характерным фальцетом, приберегаемым для подобных артистических эффектов:

— При дамах я не могу буквально повторить то, что он сказал. Поэтому я переведу его реплику на семантический язык или, лучше, на куртуазный язык «Тысячи и одной ночи»: О неосторожный незнакомец! Пожалуй, следовало бы наказать тебя ударом по лищу... <...

- При этом, - продолжал Андрей, — все богатство значений, заданных элементами «неосторожный», «незнакомец», «наказать», «удар» и «лицо», было передано с помощью ровно трех полнозначных слов, образованных от одного и того же корня. Задача имеет одно решение, - торжественно закончил он. (Жолковский 2003: 206-207) $)^{50}$

Наконец, фразеологическую версатильность обсценного слова прекрасно демонстрирует озорная частушка, известная в нескольких близких вариантах:

Полюбила парня я -

Оказался без хуя́.

49 Полностью цитату см. в наст. изд., с. 854 примеч. 12.

50 «Единственность решения и, значит, разгадка, — комментирует лингвист-мемуарист, - определяется бедностью матерной синонимии в обозначениях “лица”, тогда как в передаче остальных ключевых сем веер возможностей гораздо шире» (Там же: 207). По устному сообщению А. К. Жолковского, решение задачи звучит как «Эй ты, разъебай, щча как ёбну по ебальнику!» 
На хуя́ мне без хуя́,

Когда с ху́ем до хуя́. 51

Помимо буквального, материального значения слова хуй в сочетаниях без хуя́ и с ху́ем (вариант: $с$ хуя́мu), в частушке фигурируют метафорические сочетания на хуя́ ('зачем') и до хуя́ ('много'). Этими идиомами далеко не исчерпывается все фразеологическое богатство современного русского обсцентизма: остались, например, неиспользованными фразеологизмы ни хуя́ ('совсем') и по́ хуй ('все равно'). Таким образом, метафоризация приводит к расширению матерной фразеологии. Согласно материалам к словарю современного русского мата, собранным А. Ю. Плуцером-Сарно, число фразеологизмов со словом хуй достигает 500, со словом пизда - 800 (Плуцер-Сарно 2001, I; 2005a, II).

Аналогичные процессы происходят не только с собственно матерными, но и с грубо-просторечными словами. «Старую» ситуацию наглядно иллюстрируют слова жопа и жопный, представленные в словаре Рейфа (1835, I: 312), где зафиксированы только буквальные значения существительного и прилагательного:

ЖÓПА <...> sf. pop. le derriere, le cul.

Жо́пный, ая, оe, adj. de derrière. ${ }^{52}$

В современном языке возможны общепонятные метафоры: «жопная ситуация», «мы в жопе».

«Новую» ситуацию описывают дополнения к словарю Даля, сделанные в начале XX века Бодуэном-де-Куртенэ ${ }^{53}$, который едва ли не первым отметил и прономинализацию, и метафоризацию, и фразеологизацию слова хуй:

Хуй, род. х у я́, м., вульг. неприл., мужской дьтородный членъ. $\|$ Становится почти мъстоименіемъ въ значеніи что, что-либо, какой, какой-нибудь. Н и - х у я́ нътъ, ровно ничего нътъ. Ни-хуя́ не видно или не видать, ничего не видно. (Даль, Бодуэн-де-Куртенэ 1909: 1244)

Бодуэн зафиксировал и прилагательное ху́ев в значении 'плохой':

Ху́евъ. Это, батюшка, ху́е в о (скверное) дило, ${ }<0>{ }_{62}<$ ородское $>$. (Там же) $)^{54}$

Между тем в русских «заветных» сказках и пословицах прилагательное $x y ́ e в$ употребляется только в значении 'относящийся к мужскому половому члену'. Ср. в сказках: «Дай-ко <... поищу < ..> своему хую работы.“ <..> Вот вам хуева работа!»; в пословицах: «Молчи, хуева посудина! (т. е. баба)»; «Ах ты, хуева голова!» (т. е. glans penis); «Ах ты хуев пономарь» (т. е. онанист) (Афанасьев 1997: 123-124, 495, 487, 592)55. Три последних (послович-

51 Кабронский 1978: 105. Ударения добавлены автором настоящей статьи.

52 Перевод французских соответствий: «задница, жопа»; «[относящийся] к заднице».

53 Об этом издании см. выше, примеч. 22.

54 Дило - севернорусский диалектизм (общерус. дюло).

55 Сочетание «хуева голова» в значении 'glans penis' встречается в скоморошине «Стать почитать, стать сказывать» из сборника Кирши Данилова, составленного во второй 
ных) примера подсказывают, каким образом у обсуждаемого прилагательного могло развиться переносное пейоративное значение: метафорическое значение сперва появляется в контексте инвективы у всего словосочетания, которое, в свою очередь, представляет собой перифразу, а затем «усваивается» прилагательным. На фоне этих перифраз (значение первой из них отметили сам собиратели - В. И. Даль, А. Н. Афанасьев или П. А. Ефремов), «хуево дело» также воспринимается как перифраза 'соития', подобная «хуевой работе».

Одно из первых документальных подтверждений циркулирования прилагательного хуевый в значении 'плохой' в полной, а не краткой форме - слова деревенских мужиков, процитированные в дневниковой записи М. М. Пришвина от 25 августа 1918 г.: «Про бедноту говорите, хуевое дело, беднота - большевики, и в избу незачем входить, увидал пук удочек большевик живет» (Пришвин 2008: 181). Другой пример мы находим в записке зрителя В. Маяковскому (1929 или 1930 года), экспонированной в 2018 году в Центре авангарда на Шаболовке 56 : «Почему Вы пишите <sic!> такие хуёвые вещи<,> как “Баня”? Возмутительно!». Точки над ё, выставленные автором записки, показывают, что читать здесь следует хуёвый, а не *ху́евый:

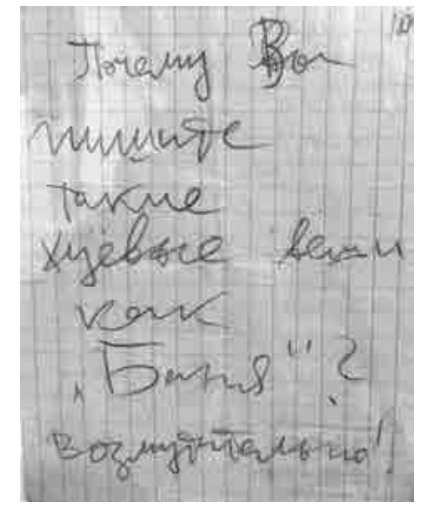

Хотя в речи наших современников прилагательное хуёвый 'плохой' вполне обычно (Беликов 2006: 51), в краткой атрибутивной форме сохраняется закономерное ударение ху́ев: «писатель ху́ев»; «железяка ху́ева» из частушки «По реке плывет топор/Из села Чугу́ева» (Кабронский 1978: 108). Аналогичное акцентное соотношение полной и краткой формы характерно и для эвфемизмов: херо́вый/хе́ров, хрено́вый/хре́нов, фиго́вый/фи́гов. Однако у краткого прилагательного в этих примерах прямое (притяжательное) значение уже утрачено. Кроме того, это прилагательное может находиться

половине XVIII века: «А и тот хоробер, да иной хоробер, / Толко нет хоробрея хуевы головы, / Он из пизды в жопу татар загнал, / А все он, ебея мать, от сабак забежал» (Топорков 1995: 35). Подробнее об этом тексте см. Rice 1976.

56 Cм.: https://www.nashabolovke-gallery.com/universalnyj-otvet-zapisochnikam 
только в постпозиции: в отличие от предыдущего состояния, порядок слов в новой идиоме не свободный, а фиксированный (Буй 2005: 95-97). Такое превращение притяжательного прилагательного в качественное сродни «народной этимологии», только реинтерпретации в данном случае подвергаются не морфемы в слове, а слова в словосочетании.

\section{7. Загадки матерной акцентологии}

Бодуэн-де-Куртенэ предполагал, что в позднейшем (отсутствовавшем у Даля) выражении «Ни черта́ не видно», «можеть быть, удареніе ни черта́, вм<Ћсто> ни чорта, подъ вліяніемъ ни хуя́» (Даль, Бодуэн-де-Куртенэ 1909: $1360)^{57}$. Сдвиг ударения отражает позднейший процесс эвфемизации (Левин 1989: 69), обратный по отношению к процессу дисфемизации, который был описан выше (§ 6). Это же явление привлекло внимание А. А. Зализняка, который искал решение для «следующей загадки русской акцентуации: почему какого чёрта, какого фи́га, но ни черта́, ни фига́?» (Зализняк 2014: 274). Использовать примеры «какого фúza» и «ни фигá» вместо «какого ху́я» и «ни хуя́» оказалось возможным, поскольку эвфемизмы фиг, хрен и хер «имеют в точности одинаковые семантические, синтаксические, морфологические и акцентные свойства», что и слово $x y и ̆$, которое Зализняк, не называя прямо, именует главой этого ряда энклиноменов или, сокращенно, «главой ряда» (Там же). Семантические свойства ряда хорошо описываются в категориях прономинализации и синонимизации:

Весь этот ряд синонимичен: корни всех этих слов имеют одно и то же «глобально-местоименное» значение - практически то же, что у слова что, только с добавлением экспрессии и общего отрицательного отношения (осудительного, пренебрежительного, насмешливого и т. п.). Например, ни фига́ в отвлечении от этих коннотаций означает то же, что ничего́, не́ фига - то же, что не́чего, за́ фигом - то же, что заче́м, и т. д. (Зализняк 2014: 274)

Обратимся теперь к акцентным свойствам. Исследователь выделил «следующие типы словоформ и словосочетаний данного класса», специально оговорив, что «в современном употреблении они как правило имеют именно такие ударения»:

а) корневое: ху́я, какого ху́я, за каким ху́ем;

б) флективное: ни хуя́, на хуя́, до хуя́;

в) предложное: на́ хуй, не́хуя, пó хую, пó хуй, за́ хуем.

Ударение может передвигаться на предлог, поскольку слово хуй сохраняет древние черты энклиномена (безударного существительного), и может передвигаться на окончание, поскольку такой сдвиг используется в русском языке для выражения фамильярной экспрессивности (ср. Зализняк 2014: 275). Ввиду того, что «акцентные свойства всех членов ряда одинаковы»,

57 Цитируемая запись взята в редакторские скобки, которые информируют читателя, что она добавлена Бодуэном. 
эвефмизмы фиг, хрен и хер ведут себя точно так же: «они все акцентные свойства получили от главы ряда» и «у всех членов <указанного> ряда реализованы все эти модели» (Зализняк 2014: 275). Однако есть исключение - «у слова чёрт реализована только их часть». У этого слова только две позиции ударения:

а) корневое: чёрта, какого чёрта, за каким чёртом;

в) флективное: ни черта́, на черта́, до черта́;

б) предложное: не засвидетельствовано.

Таким образом, слово чёрт «к этому ряду примыкает (но включилось в него неполностью, то есть уподобилось не по всем признакам)» (Там же). Между тем чёрт по своим исконным акцентологическим свойствам, наоборот, был гораздо ближе к хую, чем позднейшие эвфемизмы (Там же). Отчего же чёрт проявил неожиданную строптивость? Почему эвфемизмы хер, хрен и фиг воспроизводят парадигму «главы ряда» обсценных энклиноменов полностью, а слово чёрт только отчасти, и почему $x y и ̆$ в отдельных формах сохраняет корневое ударение (группа «а»)?

А. А. Зализняк интерпретировал все рассмотренные вторичные изменения как результаты процессов эвфемизации:

Структура этого ряда такова, что каждый следующий член в момент своего появления имел функцию эвфемизма по отношению к предыдущему члену. Первая эвфемистическая замена главы ряда - хер. Характер замены здесь совершенно такой же, как в нынешних бэ, гэ, же: слово заменяется алфавитным названием его первой буквы. Со временем эвфемизм сам начал ощущаться как нецензурный и стал заменяться (уже по модели нынешнего блин - с сохранением основных согласных корня) на хрен <... . Но в дальнейшем и этот эвфемизм тоже начинает ощущаться как слишком грубый и заменяется на сравнительно слабое слово фиг (полученное морфологическим уподоблением слова фига 'кукиш' остальным словам данного ряда и с опорой на непристойный смысл данного жеста). (Зализняк 2014: 274)

Действительно, «в сфере русских нецензурных и полуцензурных выражений существует особый тип уподобления одних единиц другим по семантическим, синтаксическим, морфологическим и акцентным свойствам» (Там же), однако уподобление это является результатом двух разновременных и разнонаправленных процессов — не только эвфемизации, о которой писал А. А. Зализняк, но и дисфемизации. В данном случае именно обращение к хронологически организованному материалу позволяет «уяснить себе исторический процесс и усвоить правила игры аналогий» (Якобсон 1971: 154). Рассмотрим этот процесс подробнее.

(1) «пойти к чёрту» $\rightarrow$ «пойти к ху́ю»

$(2) 《(a)$ бог (его) знает!» $\rightarrow$ «(a) чёрт (его) знает!» $\rightarrow «(a)$ хуй (его) знает!»

Как уже было сказано, весь ряд фразеологизмов чёрта из Пословиц русского народа не находит матерных параллелей в «заветных» пословицах 
и сказках и не является, таким образом, серией эвфемизмов хуя. Современная фразеология хуя в этом сегменте сохраняет антропоморфную актантость чёрта (может ли «хуй» что-то «знать»? и можно ли «К нему» пойти?).

(3) «какого чёрта» $\rightarrow$ «какого ху́я»

Ранняя дисфемизация, засвидетельствованная «заветными» сказками наравне с посыланием «к чёрту» и «к хую»: «какого ты чорта волькаешь?»; «Какого ж ты хуя делала, коли ничего не приготовила?» (Афанасьев 1865 / 1872: 165; 1997: 192, 432; Плуцер-Сарно 2001, I: 205-206).

(4а) ничего́ $\rightarrow$ ни чёрта

(4б) ничего́ $\rightarrow$ ни хуя́ $\rightarrow$ ни черта́

Первый этап процессов дисфемизации / эвфемизации («что $\rightarrow$ чёрт»). Первоначальное ударение - корневое, ср. в письмах Пушкина (1906, I: 68, 279): «тутъ утонешь самъ, а ни чорта не сыщешь» (П. А. Вяземскому, 6 февраля 1823 г.); «въ Войнъ я ни чорта не понимаю» (Л. С. Пушкину, февраль 1825 г.). Похоже, что именно от «ничего» исходил первоначальный толчок в дисфемизации местоимения что, поскольку замена «ничего» на «ни чёрта» ясно семантически мотивирована в поговорке: «Нђтъ ни чорта, ни дьявола (никого, ничего)»; ср. «нечертыхательную» параллель: «НБтъ ни вороху, ни пороху» (Даль 1862: 599).

Второй этап («что $\rightarrow$ хуй») проходил одновременно с первым или немногим позже. Хотя выражение ни хуя́ не встречается ни в текстах Пушкина, ни в заветных сказках, оно имеется в позднейших добавлениях к пословицам, сделанных Афанасьевым и Ефремовым: «Ни хуя хуящаго (Приговор$\kappa a$.)»; «Живешь - ебешь, помрешь - ни хуя не останется» (Афанасьев 1997: 498, 585) - а также в песне, находящейся в той же рукописи из собрания Даля: «Одну ночь он караулил -/Ничего не видал,/И другую караулил - Ни хуя не видал» (Там же: 525). Самое раннее литературное употребление ни хуя́ в значении 'ничего’ засвидетельствовано в скабрёзной поэме «Лука Мудищев» (вторая половина XIX века):

Судьбою не был он балуем,

И про Луку сказал бы я:

Судьба его снабдила хуем,

Не давши больше ни хуя.

(Вариант:

Не дав в придачу ни хуя.)

(Сапов 1994: 257, 338)

Использованная талантливым анонимом каламбурная омонимия предсказывает аналогичный прием в цитированной выше частушке, однако 150 лет назад в распоряжении поэта было гораздо меньше обсценных фразеологизмов, чем век спустя. 
Третий этап («хуй $\rightarrow$ чёрт») описан Бодуэном как инновация (ни черта́ по модели ни хуя́).

(5а) на что́ $\rightarrow$ на чёрта

(5б) на что́ $\rightarrow$ на хуя́ $\rightarrow$ на черта́

$(5$ в) на что́ $\rightarrow$ на чёрта $\rightarrow$ на кой чёрт? $\rightarrow$ кой чёрт? $\rightarrow($ на) кой хуй?

И в Заветных русских сказках, и в Девичьей игрушке «на что?» в зна-

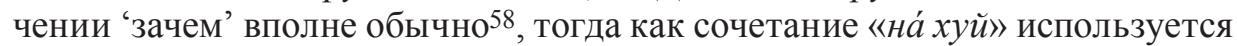
только в чисто техническом смысле ${ }^{59}$. Ни в «заветных» сказках, ни в Девичьей игрушке вопросительные конструкции с местоимениями кой и какой с существительным $x y и ̆$ не сочетаются.

Первый этап («что $\rightarrow$ чёрт»). Речение «На чорта?» включено в сборник Даля. Оборот «на кой чорт?» встречается в Пословицах Даля и в Девичьей игрушке: «Нет нужды в том, на кой чорт толковать» (Барков и др. 1992: 164). Ср. в письмах Пушкина (1906, I: 44, 202): «Своего портрета у меня нЊтъ — да на кой чортъ имЂть его» (Н. И. Гнедичу. 13 мая 1823 г.); с эллипсисом предлога на: «<..> готовъ помђстить въ честь его цђлый куплеть въ 1-ую пъснь Онъгина (да кой чортъ! говорятъ, онъ сердится, если объ немъ упоминають <..>> (Л. С. Пушкину, апрель 1825 г.).

Второй этап («что $\rightarrow x y \breve{u ») . ~ В ~ р а н н е м ~ к о р п у с е ~ п р и м е р ы ~ и с п о л ь з о в а н и я ~}$ «на хуя́»» отсутствуют. Бодуэну они также неизвестны, но должны хронологически предшествовать примерам третьего этапа 1920-х годов. Вероятная датировка второго этапа — 1900-е и 1910-е годы. Дисфемизм «На кой xyü?» также появляется в начале XX века; примеры — в обсценной пародии на Грибоедова (нач. ХХ в.); в письме Есенина А. М. Сахарову от 1 июля 1922 г. из Дюссельдорфа60.

Третий этап («xуц̆ $\rightarrow$ чёрт»). Еще в 1920-е и 30-е годы конкурируют исходная форма на чёрта (В. Шершеневич, 1923; А. Штейнберг, 1931; М. Тарловский, 1935) и вторичная на черта́ (В. Маяковский, 1921) - по модели «на хуя́» (НКРЯ).

58 Афанасьев 1997: 162, 207, 305, 416; Барков и др. 1992: 128, 137, 239, 245, 292, 298, 308.

59 Ср. в Девичьей игрушке: «[Черти] Боятся, чернецу чтоб на́ хуй не попасть» (Барков и др. 1992: 156); «И с трепетом тебя я на́ хуй ожидаю» (Там же: 265); «Но твой прехрабрый брат, презревши вонь сию/И приподняв рукой шматинищу свою, /Ударил ею в лоб злодея Хуестана/И на землю поверг елдой <своей> тирана. / Потом поднял его и на́ хуй посадил/ И по муде в него елдак свой вколотил» (Там же: 274; ударения во всех цитатах добавлены автором статьи). В сказках: «"Дай-ка я теперича залезу к нему на хуй”, - думает теща, взлезла и давай на хую покачиваться» (Афанасьев 1997: 82). Ср. также: «-Бел хуй вам под валёк, красныя девицы! - Черна́ пизда тебе на́ хуй, доброй мо́лодец!» (Там же: 458; ударения в источнике). Пословица «Либо рыбку съесть, либо на хуй сесть» (Там же: 494) знаменита, в том числе, благодаря Пушкину, который писал Вяземскому из Одессы в апреле 1824 года: «<..> или рыбку съъсть, или на хуй състь. Дамы принимаютъ эту пословицу въ обратномъ смыслъ» (Пушкин 1906, I: 106).

60 «Ч а ц и й. На кой же хуй меняться мне везде!» (Сапов 1994: 194); «Порой мне хочется послать все это к ебенейшей матери и навострить лыжи обратно. $<. .>$ Еб их проеби в распроебу. Конечно, кой-где нас знают, кой-где есть стихи переведенные, $<. .>$ но на кой хуй все это, когда их никто не читает» (Есенин 1999: 140). 
Четвертый этап. Для современной ситуации обычна синонимия на кой xýŭ / на хуя́ / нá хуй в значении ‘зачем’ (Буй 2005: 39-40): у базового «на хуя́» появляется аллегроформа на́ хуй со сдвигом ударения на предлог. Таким образом, «на́ хуй» в сочетании «на́ хуй (это) нужно?» и «на́ хуй» в сочетании «иди на́ хуй» имеют разное происхождение; соответственно, материальное значение слова хуй сохраняется во втором случае и утрачивается в первом. Старое «на чёрта» меняет ударение на «на черта́»», однако форма *нá черт так и не появляется, потому что существительное чёрт (др.-рус. чьртъ) полностью утратило свойства энклиномена (ср. Зализняк 1985: 137 [§2.17]; 2019: 622; 2014: 275).

(6а) не́чего $\rightarrow$ не́ хуя $\rightarrow$ не́ хуй

(6б) не́зачем $\rightarrow$ не́ хуем $\rightarrow$ не́ хуй

Первый этап («что $\rightarrow$ хуй»). Ранняя и непосредственная дисфемизация «что»: «Хорош зять, да не́ хуй взять»; «Не́ хуем петь, когда (коли) голосу нет» (Афанасьев 1997: 505, 497; в обоих случаях ударение в источнике). Нередуцированные формы «не́ хуя», «не́ хуем» имеют устойчивое ударение, поскольку «здесь не из нъ ('нет, не имеется'), которое было самоударным словом и в сочетании с другими словами ударения никогда не теряло» (Зализняк 2014: 275). В современном языке (второй этап) и «не́ хуя», и «не́ хуем» упрощаются в «не́ хуй».

(7a) зачем $\rightarrow$ за чёртом $\rightarrow$ за каким чёртом $\rightarrow$ за каким ху́ем

(7б) зачем $\rightarrow$ за чёртом $\rightarrow\left[{ }^{*}\right.$ за ху́ем $] \rightarrow$ за́ хуем $\rightarrow\left[{ }^{*}\right.$ за́ чертом $]$

Первичный дисфемизм датируется серединой XIX века, в литератуpe - c 1850-х годов. Самый ранний пример выражения «за чёртом» в значении ‘зачем’ найден у Ф. М. Решетникова («Где лучше?», 1868). С того же времени - более распространенное «за каким чёртом» (НКРЯ): у И. С. Никитина (Дневник семинариста, 1860), А. И. Левитова (Погибщее, но милое создание, 1862), В. В. Крестовского (Петербургские трущобы, 1864). В переводной литературе это выражение появляется чуть раньше (Библиотека для чтения, 1854; Русский вестник, прил., 1858). Вторичный дисфемизм «за́ хуем» появляется веком позже. Акцентные формы *за ху́ем и *за́ чертом не засвидетельствованы.

Итак, материал показывает, что исторически три серии дисфемизаций («что $\rightarrow$ чёрт»), «что $\rightarrow x y и ̆ 》$ и «чёрт $\rightarrow x y и ̆ »)$ предшествовали двум сериям эвфемизаций («хуй $\rightarrow$ чёрт»» и «хуй $\rightarrow x е р \rightarrow x р е н \rightarrow ф и г »)$.

Корневое ударение в группе «а» (чёрта, какого чёрта, за каким чёртом, к чёрту и ху́я, какого ху́я, за каким ху́ем, кху́ю) отражает первичный процесс дисфемизмизации (хуй является дисфемизмом чёрта, их акцентные формы совпадают). Возможно, именно из-за влияния акцентно-морфологической модели «какого чёрта» слово хуй в сочетании «какого ху́яя» противится экспрессивному сдвигу ударения на флексию. 
Сдвиг ударения на окончание в группе «б» (ни хуя́, на хуя́, до хуя́ и ни черта́, на черта́, до черта́) отражает процесс позднейшей эвфемизмизации (чёрт становится эвфемизмом хуя и наследует его экспрессивное флективное ударение; ср. новое «на черта́» при старом «на чёрта»).

Отсутствующие у чёрта формы группы «в» с ударением на предлоге (*за́ чертом) могли бы образоваться в процессе дальнейшей эвфемизации по аналогии с реально существующим «за́ хуем», однако существительное чёрт утратило свойства энклиномена и такие формы у него не образуются. Напротив, «чистые» эвфемизмы хер, хрен и фиг такие свойства приобрели, и мы теперь посылаем всех на́ хер, на́ хрен и на́ фиг (Зализняк 2014: 275).

\section{8. Русский мат в зеркале языковой игры}

К числу «новых» особенностей русского мата следует отнести и отмеченные в статье Дрейзина и Пристли элементы особой грамматики, отличной от грамматики общенационального языка, но разделяемой матом с другими (нематерными) сферами инвективного словоупотребления. Прежде всего это обязательный в некоторых позициях детерминатив (determinative adjective), без которого матерное слово перестает быть своеобразным «местоимением» и возвращает себе первоначальное материальное значение (Dreizin, Priestly 1982: 236-237; Ermen 1993: 56-57). Например, можно сказать: «И тут подходит ко мне какой-то хуй...» или «Подходит ко мне как-то раз один хуй...», но нельзя сказать в том же смысле: «Подходит ко мне хуй», потому что это будет уже означать, что ко мне подходит персонализированный половой орган (такого рода абсурдно-комические олицетворения встречаются в матерных частушках, см. Топорков 1995: 472-476, 518-520). Аналогичным образом можно сказать: «...и эта пизда мне говорит: ...», но нельзя в том же смысле сказать: «...и говорит мне пизда: ...»61

Обычно роль детерминативов выполняют местоименное прилагательное один (одна, одно) в значении 'какой-то’ (или само неопределенное местоимение какой-то) и указательное местоимение этот (эта, это), то есть те слова, которые в других языках трансформировалась в артикли - неопределенный (англ. $a(n), \phi p$. un $(e)$, нем. ein $(e)(r / s)$ и т. д.) и определенный (англ. the, фp. le/la, нем. der/die/das и т. д.). Неопределенные артикли этимологически восходят к прилагательному со значением 'один', определенные - к указательному местоимению со значением '(э)тот'.

Точно так же ведут себя и другие оскорбительные слова - просто грубые или используемые в таком качестве, например, инвективные зоо-

61 У процитированной выше частушки «Полюбила парня я...» есть вариант первой строки: «Полюбила я хуя́...» (Кабронский 1978: 107), в которой существительное хуй без детерминатива употреблено в значении 'некий человек' (Ermen 1993: 51, примеч. 1). Однако, по-видимому, такое употребление нельзя признать «нормативным» и следует интерпретировать как эллипсис (ср. Буй 2005: 18): «Полюбила я [одного] хуя́ ...» (вместо «[одного] ху́я»: ударение тоже «ненормативно»). Зато в этом варианте частушки все четыре рифмующихся слова тавтологичны - ради этого стоило нарушить законы матерной грамматики! 
нимы. Из формулировки «Подходит ко мне один козел (одна овца), и этот козел (эта овца) говорит мне...» ясно, что речь идет не о животном, а о человеке. А вот фразу «Подходит ко мне козел (овца)» невозможно проинтерпретировать как описание человека, а не животного. Отсутствие детерминатива возвращает зоониму исходное, буквальное значение. Значит, такая грамматика не является особым свойством матерных слов, а представляет собой следствие их тотальной метафоризации (свободного переноса значений), переходящей в прономинализацию (приобретение контекстных значений).

Наконец, еще одна любопытная черта «нового» русского мата памятна в литературе истекшего столетия по Одному дню Ивана Денисовича: это использование матерных корней для образования словесных пар типа «ма́слице-хуя́слице» (Dreizin, Priestly 1982: 244-245; Беликов 1990). Из цензурных соображений автор заменил начальную букву $x$ буквой $\phi$ : «На столике у них маслице да фуяслице, плащи на крючках покачиваются, чемоданчики в чехолках» (Солженицын 1962: 41). Есть в повести Солженицына и другие матерные слова-дубликаты: «Хорошо положили, а? За полдня. Без подъемника, без фуёмника» (Там же. С. 48).

Такой механизм окказионального словообразования известен издавна. Один из способов порождения новых слов в разного рода тайных языках замена первого слога любого слова условным маскировочным слогом. Например, в офенском языке в качестве «криптопрефиксов» использовались элементы ши-, шу-, ку- и нек. др.: шур 'вор', шуровать 'воровать' и подобные (Лихачёв 1964: 339-340; Бондалетов 1980: 40-51; Приёмышева 2009, I: 228-229). Если в тайных и условных языках оригинал замещается дубликатом, то в других видах префиксальной и псевдопрефиксальной редупликации оба слова, отражаемое и отражающее, предъявляются в речи одновременно.

В русском языке и фольклоре широко распространен феномен «м-редупликации»: гоголь-моголь, ёксель-моксель и др. (Plähn 1987; Минлос 2005; Лотман 2017). Аналогичные явления обычны во многих других языках (Иванов 2004: 142-143). В ряде языков, прежде всего в тюркских, такая редупликация стилистически нейтральна, в остальных стилистически снижена (Минлос 2002; ср. Беликов 1990: 81, 84). Значение подобных слов содержит два компонента - дескриптивно-денотативный (значение «ассоциативной или репрезентативной множественности»: ' $\mathrm{X} u$ / или что-то подобное') и экспрессивно-эмоциональный (несерьезное либо уничижительное отношение к предмету, обозначаемому редуплицируемым словом) (Минлос 2002). В классическом примере из Солженицына хуяслице «означает все <прочие> продукты питания, находящиеся на "столике" (своеобразное “etc.”)» (Плуцер-Сарно 2005б: 171).

По своей функции слова-дубликаты могут быть дисфемизмами. Пример такого использования матерного корня встречаем уже у Пушкина, который писал любимому брату Лёвушке в феврале 1825 года: 
Здъсь письмо къ Изд.<ателю> или Пиздателю Н.<евскаго > А.<льманаха>. Прочитай его да доставь. Онъ каналья, лжеть на меня въ афишкахъ да мнъ присылаеть свое вранье - добро!62

Этот яркий пример малоизвестен, поскольку во всех публикациях писем Пушкина, кроме отдельного тиража издания 1906-1909 гг,, напечатанного для членов Академии Наук в ограниченном числе экземпляров, пушкинское словцо урезано как непристойное. Не включено оно и в Словарь языка Пушкина.

Сегодня для создания шутливо-обсценных «“паронимических производных” соответствующих необсценных слов» (Левин 1986: 72) чаще используется форманта $x y[\mathrm{j}]-$. В последние годы эта манера широко распространилась в молодежной речи. Для забавы появилась даже специальная программа - «хуефикатор» письменных текстов, позволяющая мгновенно «хуефицировать» в них все слова (то есть заменить их матерными дублетами).

Матерная редупликация может иметь значение, отличное от «ассоциативной множественности». Слово-дубликат становится как бы словом-эхом: слова́, содержащие матерный корень, подставляемый вместо другого корня или части сло́ва, нередко используются дистантно - в ответе на фразу, содержащую исходное слово (Беликов 1990: 83, 85; Лотман 2017: 660). Например, я хочу «ма́слица», а мне отказывают в грубой форме, отвечая: «хуя́слица!» (то есть «хуя́слица тебе, а не ма́слица!»). Ю. И. Левин, комментируя иллокутивный класс «обсценные выражения отказа», эксплицирует их семантику («я отказываю тебе в просимом, попутно желая оскорбить тебя») и попутно замечает: «Отказы не случайно строятся на основе корня $x y \check{\text { - }}$, что связано с наличием в семантическом спектре этого корня сильно выраженной семантемы отрицания» (Левин 1986: 64). Это семантическая инновация с архаичной генеалогией. В основе ее лежит издевательское предложение пассивной позиции в сексуальном акте или акте фелляции (ср. Кирилина 1998): «Хуя не хочешь ли, пердун эдакой!»; «Нет, - говорит, не надуешь! Хуя не хочешь ли?»; «Не хочешь ли хуя с медом?»; «Не хочешь ли хер-ка (херка) слегка?»; «На-тка пососи, да вперед не проси! (Говорят, показывая кукиш или на́ хуй.)» (Афанасьев 1997: 102, 424, 497, 495). Ср. слова Петра I, цитированные Пушкиным в письме В. Ф. Одоевскому (конец 1836 г.): «А спросить у Нъмца; а не хочетъ-ли онъ хуя?» (Пушкин 1909, III: 398).

Между словами-дубликатами и окказионализмами есть сходство, поскольку окказионализмы тоже образуются путем замены корня или псевдокоренной части сло́ва другим корнем. Берется слово типа выска́зываться/ вы́скказаться, и на его базе образуется дисфемизм либо нематерный (вblпе́ндриваться/ви́іпендриться), либо матерный (выёбываться/вьіебнуться), а матерный эквивалент может заменяться окказиональным эвфемизмом-

62 Пушкин 1906, I: 183. Автограф: ПД № 1261, л. 49об. Об этом эпизоде пушкинской литературной биографии см.: Балакин 2010. 
паронимом (выёбываться $\rightarrow$ выёживаться). Так выявляется связь между «деривационным взрывом» и появлением «эхо-слов».

Всякая семиотическая система, в том числе естественный язык и какой-то отдельный его социолект, содержит в себе определенную картину мира, общую для ее носителей. Модель мира современного русского мата, создаваемая неологизмами типа ёбнуться, наебну́ться, объеба́ть, пизды́́к, $x y я ́$ к, конечно, очень отличается от модели мира, создаваемой пушкинским матом. Это прекрасный новый мир, изобилующий неожиданными действиями и неприятными результатами. Хуяк, например, - это отглагольное междометие от хуя́чить (Timroth 1983: 151; Ermen 1993: 36, 60). Пиздыквозможно, дисфемизм к распространенному кирды́к (неизвестного происхождения). Ср. матерную частушку: «Как у елки на макушке/Соловей ебет кукушку. / Раздается наверху: / Хуяк-пиздык, чирик-ку-ку» (Кабронский 1978: 51) — и (возможно, исходный) вариант: «Раздается на суку: / Чик-чирик, кирдык-ку-ку». Обсуждаемые слова уже вошли в современную литературу, отчасти возрождающую традиции обсценного бурлеска (Тимур Кибиров, «Послание Л. С. Рубинштейну», 1989):

Мрак да злак, да футы-нуты,
флаг-бардак, верстак-кабак,
ёлки-палки, нетто-брутто,
марш-бросок, пиздык-хуяк.

(Кибиров 1989а: 116; 1989б: 101)63

Сюда же позднейшие примеры - стихотворение из цикла пародических эпитафий (Михаил Генделев, «Эпитафия Барду О. Шмакову» по мотивам стихотворения Некрасова «Памяти Добролюбова»): «Прохожий, подойдя впритык, /Не сцы на саркофаг Амбала. / Какой светильник разума пиздык! / Какое нас покинуло ебало!» (Генделев-Хермонский 1998: 103) или пастиш стихотворения Тарковского «Вот и лето прошло...» (Мирослав Немиров, 1994): «Вот и лето блядь вжик —/Как и не было его. / Вот и осень хуяк-пиздык! —/Ох, вот оно все каково» (Немиров 1999: 23) ${ }^{64}$.

Мир, моделируемый современным русским матом, очень точно определил Ю. И. Левин (1986: 71-72):

[Это] мир, в котором крадут и обманывают, бьют и боятся, в котором «все расхищено, предано, продано», в котором падают, но не поднимаются, берут, но не дают, в котором либо работают до изнеможения, либо халтурят - но в любом случае относятся к работе, как и ко всему окружающему и всем окружающим, с отвращением либо с глубоким безразличием, — и все кончается тем, что приходит полный пиздец.

63 О поэзии московского концептуализма как «нео-бурлеске» см. Pilshchikov, Shapir 2011.

64 У того же автора («Хуй и знает, друзья, что сказать...», декабрь 1990): «Оказывается, вот так, /А не по другому совсем:/Еблысь и пиздык, и хуяк, / И ничего, что затем» (Там же: 107). 
Вместе с тем современный мат характеризуется не только негативными и депрессивными тенденциями, пределом осуществления которых становится его деградация до междомётного матерного бубнения (Беликов 2005). Матерщине, как и раньше, присущ разгульный задор и здоровый комизм. Мат по-прежнему несет в себе витальный и субверсивный заряд, еще способный остранить и подорвать шельмоватое ханжество нынешнего официального дискурса. В этом сегодня заключается реанимационно-терапевтический и революционно-политический потенциал русского мата 65 .

\section{ЛИТЕРАТУРА}

Аввакум. Житие протопопа Аввакума им самим написанное и другие его сочинения. Ред., вступ. ст. и комментарий Н. К. Гудзия. [М.]: Academia, 1934.

Аникин А. Е. Русский этимологический словарь. Вып. 3. М.: Рукописные памятники Древней Руси, 2009.

Антропов Н. П. «“Гуска сологая” в свете полногласных сочетаний модели *telt». Слова, конструкции и тексты в истории русской письменности: Сборник статей к 70-летию академика А. М. Молдована. М.; СПб.: Нестор-История, 2021: 413-431.

Асташова Н. И., Зализняк А. А. «Берестяные грамоты из раскопок в Заднепровье г. Смоленска». Историческая археология. Традииии и перспективы: К 80-летию со дня рождения Д. А. Авдусина. Отв. ред. В. Л. Янин. М.: Памятники исторической мысли, 1998: $336-341$.

Афанасьев А. Н. Русские заветные сказки. Валаам [Женева]: Типографским художеством монашествующей братии, Год мракобесия [между 1865 и 1872].

Афанасьев А. Н. Народные русские сказки не для печати, заветные пословицы и поговорки, собранные и обработанные А. Н. Афанасьевым, 1857-1862. Изд. подгот. О. Б. Алексеева, В. И. Еремина, Е. А. Костюхин, Л. В. Бессмертных. М.: Ладомир, 1997.

Балакин А. Ю. «Пушкин и “Невский Альманах": заметки к теме». Пермяковский сборник. Ч. 2. М.: Новое издательство, 2010: 239-250.

Барков И. и др. Девичья игрушка, или Сочинения господина Баркова. Изд. подгот. А. Зорин и Н. Сапов [С. И. Панов]. М.: Ладомир, 1992.

Беликов В. И. «Продуктивная модель повтора в русском языке». Russian Linguistics 14.1 (1990): 81-86.

Беликов В. И. «Национальная идея и культура речи». Отечественные записки 23 (2005): 47-66.

Беликов В. И. «Границы обсценного в восприятии современной городской молодежи: типологизация идиолектов». Изменения в языке и коммуникаиии: ХХІ век. Сост. и отв. ред. М. А. Кронгауз. М.: РГГУ, 2006: 33-72.

Бессмертных Л. В. «О рукописях А. Н. Афанасьева "Народныя русския сказки не для печати (из собрания В. И. Даля)" и “Русския заветныя пословицы и поговорки (В. И. Даля)", а также об издании В. И. Касаткиным в 1867 г. книги "Русския заветныя сказки”». Народные русские сказки не для печати, заветные пословицы и поговорки, собранные и обработанные А. Н. Афанасьевым, 1857-1862. М.: Ладомир, 1997: 558-660.

Богомолов Н. А. «Примечания». М. Кузмин. Стихотворения. СПб.: Академический проект, 1996: 679-788.

Бодуэн-де-Куртенэ И. А. «Послесловие к 3-му исправленному и дополненному изданию словаря Даля». Толковый словарь живого великорусского языка Владимира Даля. 3-е, испр. и значительно доп., изд. Под ред. проф. И. А. Бодуэна-де-Куртенэ. Т. 4. СПб.; М.: М. О. Вольф, 1909.

65 Автор благодарит за ценные замечания и дополнения С. Г. Болотова, А. А. Добрицына, И. Г. Добродомова, А. В. Дыбо, А. К. Жолковского, К. Ичин, Н. И. Киреева, В. С. Отяковского, В. С. Полилову, А. А. Ромахина и - отдельно и особенно, хотя и в порядке общего алфавита, - Д. В. Сичинаву. 
Бондалетов В. Д. Условные языки русских ремесленников и торговиев: Словопроизводство. Рязань: Рязанский гос. пед. институт, 1980.

Бондалетов В. Д. В. И. Даль и тайные языки в России. М.: Флинта; Наука, 2004.

Бродский Иосиф. Конеи прекрасной эпохи. Анн Арбор: Ардис, 1977.

Бродский Иосиф. «Письма к Виктору Голышеву». Портфель: Литературный сборник. Ред.-сост. Александр Сумеркин. Dana Point, CA: Ardis, 1996: 60-76.

Бродский Иосиф. «8-е декабря 1995 г. В. П. Голышеву». Новая газета 35 (2000), 22 мая: 23.

Буй Василий. Русская заветная идиоматика: Весельй словарь народных выражений. Ред.: д. ф. н., проф. А. Н. Баранов и д. ф. н., проф. Д. О. Добровольский. Изд. 2-е, испр. и доп. М.: Альта-Принт, 2005.

[Вейсман Э.] Teutsch-Lateinisch- und Rußisches Lexikon, samt denen Unfangs-Gründen der Rußischen Sprache = Немеико-латинский и руский лез̆икон купно с первыми началами рускаго языка. [Пер. на рус. яз.: И. И. Ильинский, И. П. Сатаров и И. С. Горлицкий]. СПб.: Типография Императорской Академии наук, 1731.

Веселовская Т. М. «Кто такие лохи?». Русская речь 1 (2001): 55-58.

Виноградов В. В. Язык Пушкина: Пушкин и история русского литературного языка. М.; Л.: Academia, 1935.

Винокур Г. О. «“Борис Годунов”: [Комментарий]». А. С. Пушкин. Полное собрание сочинений. Т. VII («пробный»). Л.: Издательство АН СССР, 1935: 385-505.

Винокур Г. О. «Язык “Бориса Годунова”». Г. О. Винокур. Избранные работы по русскому языку. М.: Учпедгиз РСФСР, 1959: 301-327.

Волошинов В. Н. Марксизм и философия языка: Основные проблемы сочиологического метода в науке о языке. Изд. 2-е. Л.: Прибой, 1930.

Выготский Л. С. Мышление и речь: Психологические исследования. М.; Л.: Соцэкгиз, 1934.

Генделев-Хермонский Михаил Самьюэлевич. «Bella Tristia». Солнечное сплетение, № 1. Иерусалим, 1998: 101-103.

Горбачевич К. С. Русский синонимический словарь. СПб.: ИЛИ РАН, 1996.

Грачев М. А. «Социальные диалекты в “Толковом словаре живого великорусского языка" В. И. Даля». Вестник Нижегородского государственного университета им. Н. И. Лобачевского 6/2 (2013): 64-68.

Губер П. К. Дон-Жуанский список Пушкина. Главы из биографии с 9-ю портретами. Пб.: Издательство «Петроград», 1923.

Гудзий Н. К. «Протопоп Аввакум как писатель и как культурно-историческое явление». Житие протопопа Аввакума им самим написанное и другие его сочинения. [M.]: Aсаdemia, 1934: 7-59.

Даль В. И. «[Рец. на кн.]: Опыт Областного великорусского словаря, изданный Вторым отделением Императорской Академии Наук. 1852 г.» Вестник Императорского Русского Географического Общества 6.1 (1852), отд. IV: 1-72.

Даль В. И. Пословицы русского народа: Сборник пословии, поговорок, речений, присловий, чистоговорок, прибауток, загадок, поверий и проч. М.: В Университетской типографии, 1862.

Даль В. И. Толковый словарь живого великорусского языка. Ч. I-IV. М.: В типографии А. Семена, 1863-1866.

Даль В. И. «Условный язык петербургских мошенников, известный под именем музыки или байкового языка». Публикация и вступ. статья А. Л. Топоркова. Bonpocbl языкознания 1 (1990): 133-137.

Даль В. И., Бодуэн-де-Куртенэ И. А. Толковый словарь живого великорусского языка Владимира Даля. 3-е, испр. и значительно доп., изд. Под ред. проф. И. А. Бодуэна-де-Куртенэ. Т. I-IV. СПб.; М.: М. О. Вольф, 1903-1909.

ДБГ = Древнерусские берестяные грамоть. $\mathrm{http} / / \mathrm{gramoty} . \mathrm{ru} /$ birchbark/

Есенин С. А. Полное собрание сочинений в семи томах. Т. 6. М.: Наука; Голос, 1999.

Достоевский Ф. М. Полное собрание сочинений в 30 томах. Т. 21. Л.: Наука, 1980.

Жельвис В. И. Поле брани: Сквернословие как сочиальная проблема. Изд. 2-е, перераб. и доп. М.: Ладомир, 2001.

Живов В. М. Язык и культура в России XVIII века. М.: Школа «Языки русской культуры», 1996. 
Живов В. М. «ХОУ-ть-И: Об идиосинкратических факторах при выборе морфологических вариантов». В. М. Живов. Восточнославянское правописание XI-XIII века. М.: Языки славянской культуры, 2006: 200-224.

Жолковский Александр. Эросипед и другие виньетки. М.: Водолей, 2003.

Зализняк А. А. От праславянской акцентуации к русской. М.: Наука, 1985.

Зализняк А. А. «Поправки и замечания к чтению ранее опубликованных берестяных грамот». В. Л. Янин, А. А. Зализняк. Новгородские грамоты на бересте. Т. 10: (из раскопок 1990-1996 г2.). М.: Русские словари, 2000: 82-122.

Зализняк А. А. «К вопросу об акцентной эволюции энклиноменов в русском языке». Язык. Константы. Переменные: Памяти Александра Евгеньевича Кибрика. СПб.: Алетейя, 2014: 269-276.

Зализняк А. А. Древнерусское ударение: Общие сведения и словарь. 2-е изд., расшир. и перераб. М.: ЯСК, 2019.

Зализняк А. А., Янин В. Л. «Берестяные грамоты из новгородских раскопок 2005 г.» Bonpoсы языкознания 3 (2006): 3-13.

Змеев Л. Ф. Русские врачебники: Исследование в области нашей древней врачебной письменности. (Памятники древней письменности СXII). СПб.: Типография В. Ф. Демакова, 1895.

Зорин А. Л. «Легализация обсценной лексики и ее культурные последствия». Анти-мир русской культуры: Язык. Фольклор. Литература. Сост. Н. А. Богомолов. М.: Ладомир, 1996: 121-139.

Зыков В., Кондратьев А. «Роскомнадзор накажет СМИ только за четыре матерных слова». Известия (2013), 25 декабря. https://iz.ru/news/563178

Иванов Вяч. Вс. Лингвистика третьего тысячелетия: Вопросы к будущеему. М.: Языки славянской культуры, 2004.

Иезуитова Р. В. «Рабочая тетрадь Пушкина ПД, № 836 (История заполнения)». Пушкин: Исследования и материаль 14 (1991): 121-147.

Кабронский В. [Козловский Владимир]. Неподиензурная русская частушка. Подгот. текста, введение и примечания В. Кабронского. Предисловие проф. В. Раскина. New York: Russica Publishers, 1978.

Кибиров Тимур. «Послание Л. С. Рубинштейну». Синтаксис, № 26. Париж, 1989a: 111-121.

Кибиров Тимур. «Три послания: Отрывки из поэмы». Время и мыь, № 197. Нью-Йорк, 1989б: $100-110$.

Киреев Н. И., Сапогов И. А. «О некоторых терминах наивной венерологии от Пушкина до Бодуэна». Zeitschrift für slavische Philologie (в печати).

Кирилина А. В. Еще один аспект значения обсценной лексики. Вестник Тамбовского университета. Серия: Гуманитарные науки 4 (1998): 13-16.

Ковшова М. Л. Семантика и прагматика эвфемизмов: Краткий тематический словарь современных русских эвфемизмов. М.: Гнозис, 2007.

Ковшова М. Л. «Эвфемизмы и фразеологизмы: устойчивые структуры в аспекте эвфемизации». Вестник Московского государственного областного университета. Серия: Русская филология 14 (2019): 35-48.

Левин Ю. И. «Об обсценных выражениях русского языка». Russian Linguistics 10.1 (1986): $61-72$.

Левичева Т. И. Письма А. С. Пушкина Южного периода (1820-1824). М.: Наука, 2001.

Лернер Н. О. «Стихотворная складчина Пушкина и Дениса Давыдова (Новое четверостишие Пушкина)». Пушкин и его современники 36 (1923): 21-25.

Лихачёв Д. С. «Арготические слова профессиональной речи». Развитие грамматики и лексики современного русского языка. М.: Наука, 1964: 311-359.

Лотман Михаил. «Ёксель-моксель, ёлки-палки, (h)uina-muina и прочие штучки-дрючки». Зборник Матице српске за славистику 92 (2017): 641-673.

Лотман Ю. М. Александр Сергеевич Пушкин. Серия «Биография писателя». Л.: Просвещение, 1981.

Минлос Ф. Р. «Неточная редупликация как средство выражения значения репрезентативной множественности». Компьютерная лингвистика и интеллектуальные технологии: Труды Международного семинара «Диалог'2002» (Протвино, 6-11 июня 2002 г.). Т. 1. М.: РГГУ, 2002: 291-295. 
Минлос Ф. Р. «Рифмованные сочетания в русском фольклоре: Редупликация и парные слова». Русский язык в научном освещении 9 (2005): 96-115.

Михайлова Н. И. «“Сводня грустно за столом...” (К комментарию стихотворения А. С. Пушкина)». Временник Пушкинской комиссии 29 (2004): 198-201.

Мокиенко В. М. «Русская бранная лексика: Цензурное и нецензурное». Rusistik = Pycuстика 11/12 (1994): 50-73.

Морозов А. А. «Русская стихотворная пародия». Русская стихотворная пародия (XVIII начало $X X$ в.). (Библиотека поэта. Большая серия). Л.: Советский писатель, 1960: 5-88.

Муратов Д. А. «Явление есть, и слово есть». Новая газета 78/2655 (2017), 21 июля: 21.

Немиров Мирослав. Некоторые стихотворения, расположенные по алфавиту. Концепция и дизайн: Александр Флоренский. СПб.: Красный матрос, 1999.

НКРЯ = Национальный корпус русского языка. https://ruscorpora.ru/

Нордстет Иван. Российский, с немецким и франиузским переводами, словарь. Ч. І-ІІ. СПб.: И. К. Шнор, 1780-1782.

Осипов Б. И. «Заметки по поводу отражения табуированной лексики в бодуэновских изданиях “Толкового словаря живого великорусского языка” В. И. Даля». Acta Universitatis Szegediensis de Attila József Nominatae. Dissertationes Slavicae. Sectio linguistica 22 (1991): 31-49.

Панасюк И. Л. «Семантические и коммуникативные особенности феномена табу». «Злая лая матерная...». Сборник статей под ред. В. И. Жельвиса. М.: Ладомир, 2005: 54-68.

Панченко А. А. «Матерная брань в религиозном контексте». «Злая лая матерная...». Сборник статей под ред. В. И. Жельвиса. М.: Ладомир, 2005: 138-161.

Паперно И. А. «О двуязычной переписке пушкинской поры». Ученые записки Тартуского государственного университета 358 (1975): 148-156.

Пеньковский А. Б. Загадки пушкинского текста и словаря: Опыт филологической герменевтики. М.: Языки славянских культур, 2005.

ПВС = Пушкин в воспоминаниях современников. 3-е изд., доп. Т. 1-2. СПб.: Академический проект, 1998.

Пильщиков И. А. «Пародия и сатира в контексте споров о языке (XVIII — начало XIX в.)». Логический анализ языка: Языковые механизмы комизма. Отв. ред. Н. Д. Арутюнова. М.: Индрик, 2007: 56-69.

Пильщиков И. А. «Русская обсценная идиоматика в XIX и XX столетиях». Субстандарт в русском языке. Под ред. А. К. Бириха и М. А. Кронгауза. Berlin: Peter Lang, 2022 (в печати).

Пильщиков И., Иоффе Д. «Русский мат: вчера, сегодня, завтра». Зборник Майице срӣске за славистиику 100 (2021): 691-707.

Пильщиков И., Коняев А. «“Лента.ру” разобралась в происхождении русского мата». http:// lenta.ru/articles/2013/04/02/mat/ (страница недоступна с 8 июля 2013 г.)

Пильщиков И. А., Шапир М. И. А. С. Пушкин. Тень Баркова: Тексты. Комментарии. Экскурсы. Изд. подгот. И. А. Пильщиков и М. И. Шапир. М.: Языки славянской культуры, 2002.

Пильщиков И. А., Шапир М. И. «Еще раз об авторстве баллады Пушкина “Тень Баркова”». Известия Российской академии наук. Серия литературы и языка 64.3 (2005): 41-52.

Плуцер-Сарно А. Ю. Большой словарь мата. Т. 1: Опьт построения справочно-библиографической базы данных лексических и фразеологических значений слова «хуй». Материалы к словарю русского мата. Т. 2: Опыт построения справочно-библиографической базы данных лексических и фразеологических значений слова «пизда». СПб.; М.: Лимбус Пресс, 2001-2005а.

Плуцер-Сарно А. Ю. «Заметки о русском мате». «Злая лая матерная...». Сборник статей под ред. В. И. Жельвиса. М.: Ладомир, 2005б: 162-205.

ПОС = Псковский областной словарь с историческими данными. Под ред. Л. А. Ивашко, И. С. Лутовиновой, М. А. Тарасовой. Вып. 19. СПб.: Издательство СПбГУ, 2008.

Потапов С. М. Словарь жаргона преступников (блатная музыка). Составил по новейшим данным С. М. Потапов. М.: НКВД, 1927.

Приёмышева М. Н. «И. И. Срезневский об офенском языке («офенско-русский» и «русско-офенский» словари И. И. Срезневского 1839 г. Из собрания ПФА РАН)». Acta 
Linguistica Petropolitana. Труды института лингвистических исследований 3 (2007): 335-360.

Приёмышева М. Н. Тайные и условные языки в России ХІХ в. Ч. I-II. СПб.: Нестор-История, 2009.

Пришвин М. М. Дневники, 1928-1929. М.: Русская книга, 2004.

Пришвин М. М. Дневники, 1918-1919. М.: Русская книга, 2008.

«Прожито» = Текстовый корпус личных дневников «Прожито». https://prozhito.org/

Пропп В. Я. Исторические корни волшебной сказки. Л.: Издательство ЛГУ, 1946.

Пропп В. Я. «Ритуальный смех в фольклоре (По поводу сказки о Несмеяне)». В. Я. Пропп. Фольклор и действительность. М.: Наука, 1976: 174-204.

Путилин И. Д. «Условный язык Петербургских мошенников, известный под именем “Музыки” или "Байкового языка"». Записки И. Д. Путилина. Кн. 4. СПб.: Книгоиздание И. А. Сафонова, 1904: 261-267. Фототипический репринт в кн.: Собрание русских воровских словарей в четырех томах / Сост. и примеч. В. Козловского. Т. 1. New York: Chalidze Publications, 1983: 63-71.

Пушкин А. С. Стихотворения Александра Пушкина. Ч. 1. СПб.: В Типографии Департамента народного просвещения, 1829.

Пушкин А. С. Борис Годунов. СПб.: В Типографии Департамента народного просвещения, 1831.

Пушкин А. С. Сочинения: Переписка. Т. I-III. СПб.: Типография Императорской Академии наук, 1906-1909.

Пушкин А. С. Полное собрание сочинений. Т. I-XVI. М.; Л.: Издательство АН СССР, 19371949.

Пушкин А. С. Письма к жене. Л.: Наука, 1986.

Пушкин А. С. Рабочие тетради. T. IV. СПб.; Лондон: Институт русской литературы (Пушкинский Дом) РАН, 1996.

Пушкин А. С. Полное собрание сочинений в 20 томах. Т. 7. СПб.: Наука, 2009.

Пушкин А. С. Полное собрание сочинений в 20 томах. Т. 2, кн. 2. СПб.: Наука, 2016.

Ранчин А. М., Сапов Н. Стихи не для дам: Русская нецензурная поэзия второй половины ХІХ века. Изд. подгот. А. Ранчин и Н. Сапов [С. И. Панов]. М.: Ладомир, 1994.

Рейф Филипп. Русско-франиузский словарь, в котором русские слова расположены по происхождению; или Этимологический лексикон русского языка. T. I-II. СПб.: В Типографии Н. Греча, 1835-1836.

Ромашенкова Т., Усманов 3. «Мат городов русских». Итоги 39/485 (2005), 26 сентября. http://www.itogi.ru/archive/2005/39/59573.html

Сапов Н. Под именем Баркова: Эротическая поэзия XVIII - начала ХХ века. Изд. подгот. Н. Сапов [С. И. Панов]. М.: Ладомир, 1994.

Словарь РЯ XVIII = Словарь русского языка XVIII века. Вып. 2. Л.: Наука, 1984.

Солженицын А. И. «Один день Ивана Денисовича». Новый мир 11 (1962): 8-74.

Срезневский И. И. Материаль для словаря древне-русского языка по письменнымм памятникам. Т. I-III. СПб.: Типография Императорской Академии наук, 1893-1903.

Топорков А. Л. Русский эротический фольклор. Сост. и науч. ред. А. Л. Топорков. М.: Ладомир, 1995.

Трубачев О. Н. «Из работы над русским Фасмером: К вопросам теории и практики перевода». Вопросы языкознания 6 (1978): 15-24.

Трунин М. В. «Домашняя семантика в фельетонах А. В. Дружинина: Как понять “Чернокнижникова"?». Зборник Матиие српске за славистику 92 (2017): 383-411.

Успенский А. А. «Реестр словам Офенского наречия». Труды Общества любителей Российской словесности при Императорском Московском университете 20 (1820): 239 242.

Успенский Б. А. «Религиозно-мифологический аспект русской экспрессивной фразеологии». Структура текста - 81: Тезисы симпозиума. М.: Институт славяноведения и балканистики АН СССР, 1981: 49-53.

Успенский Б. А. «Мифологический аспект русской экспрессивной фразеологии». Б. А. Успенский. Избранные трудыл. Т. 2: Язылк и культура. М.: Гнозис, 1994: 53-128.

Успенский Б. А. «“Заветные сказки” А. Н. Афанасьева». Анти-мир русской культуры: Язык. Фольклор. Литература. Сост. Н. А. Богомолов. М.: Ладомир, 1996: 143-164. 
Ушаков Д. Н. Толковый словарь русского языка. Под ред. проф. Д. Н. Ушакова. Т. І. М.: Государственный институт «Советская энциклопедия»; ОГИЗ, 1935.

Фасмер М. Этимологический словарь русского языка. Пер. с нем. и доп. О. Н. Трубачева. T. I-IV. М.: Прогресс, 1964-1973.

Цявловский М. А. «Комментарии». А. С. Пушкин. Тень Баркова: Тексты. Комментарии. Экскурсы. Изд. подгот. И. А. Пильщиков и М. И. Шапир. М.: Языки славянской культуры, 2002: 164-299.

Черейский Л. А. Пушикин и его окружение. 2-е изд., доп. и перераб. Л.: Наука, 1989.

Чупринин С. И. «Жизнь по понятиям». Знамя 12 (2004): 140-155.

Шапир М. И. «Феномен Батенькова и проблема мистификации (Лингвостиховедческий аспект. 1-2)». Philologica 4 (1997): 85-139.

Шапир М. И. «К семантике “пародического балладного стиха” (“Тень Баркова” в контексте полемики о старом и новом слоге)». М. И. Шапир. Universum versus: Язык - cmuх смыслл в русской поэзии XVIII-XX веков. Кн. 1. М.: Языки русской культуры, 2000: $192-223$.

Шапир М. И. «Барков и Державин: Из истории русского бурлеска». А. С. Пушкин. Тень Баркова: Тексты. Комментарии. Экскурсы. Изд. подгот. И. А. Пильщиков и М. И. Шапир. М.: Языки славянской культуры, 2002: 397-457.

Эйхенбаум Б. М. «Литературная домашность». Б. Эйхенбаум. Мой временник: Словесность, наука, критика, смесь. Л.: Издательство писателей в Ленинграде, 1929: 82-86. Напечатано под загл. «Предисловие» в кн.: Аронсон М., Рейсер С. Литературные кружки и салоны. Ред. и предисловие Б. М. Эйхенбаума. Л.: Прибой, 1929: 3-7.

ЭССЯ = Этимологический словарь славянских языков: Праславянский лексический фонд. Под ред. чл.-корр. АН СССР О. Н. Трубачева. М.: Наука, 1975. Вып. 2; 1979. Вып. 6; 1981. Вып. 8; 1990. Вып. 16; 1994. Вып. 20.

Юрганов А. Л. «Из истории табуированной лексики: Что такое “блядь” и кто такой “блядин сын” в культуре русского средневековья». Одиссей. Человек в истории. М.: Наука, 2000: 194-206.

Якобсон Р. О. «Морфологические наблюдения над славянским склонением (состав русских падежных форм)». Roman Jakobson. Selected Writings. Vol. II: Word and Language. The Hague; Paris: Mouton, 1971: 154-183.

Янин В. Л., Зализняк А. А., Гиппиус А. А. Новгородские грамоты на бересте. Т. 12: (из раскопок 2001-2014 гz.). М.: Языки славянской культуры, 2015.

Adams J. N. "Words for 'Prostitute' in Latin". Rheinisches Museum für Philologie 126.3/4 (1983): 321-358.

Carey Claude. Les proverbes érotiques russes: Études de proverbes recueillis et non-publiés par Dal' et Simoni. Slavistic Printings and Reprintings 88. The Hague; Paris: Mouton, 1972.

Dreizin Felix, Priestly Tom. "A Systematic Approach to Russian Obscene Language". Russian Linguistics 6.2 (1982): 233-249.

Ermen Ilse. Der obszöne Wortschatz im Russischen: Etymologie - Wortbildung — SemantikFunktionen. Specimina Philologiae Slavicae 98. München: O. Sagner, 1993.

Hamp Eric P. "Albanian pidh : Slavic peizdla $\bar{a}$ ". International Journal of Slavic Linguistics and Poetics 11 (1968): 25-26.

Jakobson Roman. "New Slavic Etymological Dictionaries". Word 8.4 (1952): 387-394.

Kovalev Manuela. "From an unprintable to a printable language of literature? Russian obscene language in late and post-Soviet literary cultures". Russian Journal of Communication 6.2 (2014): 113-126.

Lunt Horace G. "Slavic *jbgra 'Dance, Game, Play'." Papers in Slavic Philology 1. In Honor of James Ferrell. Edited by Benjamin A. Stolz. Ann Arbor: Michigan Slavic Publications, 1977: 172-177.

Minorsky V. "Khāqānī and Andronicus Comnenus". Bulletin of the School of Oriental and African Studies, University of London 11.3 (1945): 550-578.

Oguibénine Boris. L'héritage du lexique indo-européen dans le vocabulaire russe: Compléments au Dictionnaire étymologique de la langue russe de M. Vasmer. Paris: Institut d'études slaves, 2016.

Pedersen Holger. "Litauisch skujà". Jagić-Festschrift: Zbornik u slavu Vatroslava Jagića. Berlin: Weidmannsche Buchhandlung, 1908: 218-219. 
Pilshchikov Igor. "'If Only Pushkin Had Not Written This Filth': The Shade of Barkov and Philological Cover-ups". Taboo Pushkin: Topics, Texts, Interpretations. Ed. by Alyssa Dinega Gillespie. Madison: University of Wisconsin Press, 2012: 159-184.

Pilshchikov Igor, Shapir Maksim. "Avant-Gardism of the Classics and Classicality of the AvantGarde: Communication Strategies of Moscow Conceptualism in the Context of the Evolution of Styles in Russian Poetry from the Eighteenth to the Twentieth Century". Translated by Joseph Peschio and Igor Pilshchikov. Russian Literature 69.2/4 (2011): 383-392.

Plähn Jürgen. «Хуйня-муйня и тому подобное». Russian Linguistics 11.1 (1987): 37-41.

Rann James. "Review of: Taboo Pushkin: Topics, Texts, Interpretations. Ed. by Alyssa Dinega Gillespie. Madison: University of Wisconsin Press, 2012 [etc.]". Modern Language Review 109.2 (2014): 584-586.

Raskin Victor. "On Some Pecularities of Russian Lexikon". Papers from the Parasession on the Lexicon. Chicago Linguistic Society, April 14-15, 1978. Ed. by Donka Farkas, Wesley M. Jacobsen, Karol W. Todrys. Chicago: Chicago Linguistic Society; University of Chicago, 1978: 312-325.

Razvratnikov, Boris Sukitch. "Elementary Russian Obscenity”. Maledicta 3.2 (1979): 197-204.

Rice James L. A Russian Bawdy Song of the Eighteenth Century. Slavic and East European Journal 20.4 (1976): 353-370.

Schruba Manfred. "Zur Spezifik der russischen obszönen Dichtungen des 18. Jahrhunderts (Barkoviana) vor dem Hintergrund der französischen Pornographie". Zeitschrift für slavische Philologie 59.1 (2000): 47-65.

Taranovsky Kiril. "The Rhythmical Structure of the Notorious Russian Poem Luka". International Journal of Slavic Linguistics and Poetics 25/26 (1982): 429-432.

Timroth Wilhelm von. Russische und sowjetische Soziolinguistik und tabuisierte Varietäten des Russischen (Argot, Jargons, Slang und Mat). Slavistische Beiträge 164. München: O. Sagner, 1983.

Vasmer Max. Russisches etymologisches Wörterbuch. Bd. I-III. Heidelberg: C. Winter, 1953-1958.

\section{LITERATURE}

Adams J. N. "Words for 'Prostitute' in Latin”. Rheinisches Museum für Philologie 126.3/4 (1983): 321-358.

Afanas'ev A. N. Russkie zavetnye skazki. Valaam [Geneva]: Tipografskim khudozhestvom monashestvuiushchei bratii, God mrakobesiia [mezhdu 1865 i 1872].

Afanas'ev A. N. Narodnye russkie skazki ne dlia pechati, zavetnye poslovitsy i pogovorki, sobrannye i obrabotannye A. N. Afanas'evym, 1857-1862. Izd. podgot. O. B. Alekseeva, V. I. Eremina, E. A. Kostiukhin, L. V. Bessmertnykh. M.: Ladomir, 1997.

Anikin A. E. Russkii etimologicheskii slovar'. Vyp. 3. M.: Rukopisnye pamiatniki Drevnei Rusi, 2009.

Antropov N. P. “'Guska sologaia' v svete polnoglasnykh sochetanii modeli *telt”. Slova, konstruktsii $i$ teksty $v$ istorii russkoi pis'mennosti: Sbornik statei $k$ 70-letiiu akademika A. M. Moldovana. M.; SPb.: Nestor-Istoriia, 2021: 413-431.

Astashova N. I., Zalizniak A. A. "Berestianye gramoty iz raskopok v Zadneprov'e g. Smolenska". Istoricheskaia arkheologiia. Traditsii i perspektivy: $K$ 80-letiiu so dnia rozhdeniia D. A. Avdusina. Otv. red. V. L. Yanin. M.: Pamiatniki istoricheskoi mysli, 1998: 336-341.

Avvakum. Zhitie protopopa Avvakuma im samim napisannoe i drugie ego sochineniia. Red., vstup. st. i kommentarii N. K. Gudziia. [M.]: Academia, 1934.

Balakin A. Yu. "Pushkin i 'Nevskii Al'manakh': zametki k teme”. Permiakovskii sbornik. Ch. 2. M.: Novoe izdatel'stvo, 2010: 239-250.

Barkov I. i dr. Devich'ia igrushka, ili Sochineniia gospodina Barkova. Izd. podgot. A. Zorin i N. Sapov [S. I. Panov]. M.: Ladomir, 1992.

Baudouin-de-Courtenay I. A. "Posleslovie k 3-mu ispravlennomu i dopolnennomu izdaniiu slovaria Dalia”. Tolkovyi slovar' zhivogo velikorusskogo yazyka Vladimira Dalia. 3-e, ispr. i znachitel'no dop., izd. Pod red. prof. I. A. Boduena-de-Kurtene. T. 4. SPb.; M.: M. O. Vol'f, 1909. 
Belikov V. I. “Produktivnaia model' povtora v russkom yazyke”. Russian Linguistics 14.1 (1990): $81-86$.

Belikov V. I. “Natsional'naia ideia i kul'tura rechi”. Otechestvennye zapiski 23 (2005): 47-66.

Belikov V. I. "Granitsy obstsennogo v vospriiatii sovremennoi gorodskoi molodezhi: tipologizatsiia idiolektov". Izmeneniia v yazyke i kommunikatsii: XXI vek. Sost. i otv. red. M. A. Krongauz. M.: RGGU, 2006: 33-72.

Bessmertnykh L. V. “O rukopisiakh A. N. Afanas'eva 'Narodnyia russkiia skazki ne dlia pechati (iz sobraniia V. I. Dalia)"” i 'Russkiia zavetnyia poslovitsy i pogovorki (V. I. Dalia)', a takzhe ob izdanii V. I. Kasatkinym v 1867 g. knigi 'Russkiia zavetnyia skazki'.” Narodnye russkie skazki ne dlia pechati, zavetnye poslovitsy i pogovorki, sobrannye i obrabotannye A. N. Afanas'evym, 1857-1862. M.: Ladomir, 1997: 558-660.

Bogomolov N. A. "Primechaniia”. M. Kuzmin. Stikhotvoreniia. SPb.: Akademicheskii proekt, 1996: 679-788.

Bondaletov V. D. Uslovnye yazyki russkikh remeslennikov i torgovtsev: Slovoproizvodstvo. Riazan': Riazanskii gos. ped. institut, 1980.

Bondaletov V. D. V. I. Dal' i tainye yazyki v Rossii. M.: Flinta; Nauka, 2004.

Brodskii Iosif. Konets prekrasnoi epokhi. Ann Arbor: Ardis, 1977.

Brodskii Iosif. "Pis'ma k Viktoru Golyshevu". Portfel': Literaturnyi sbornik. Red.-sost. Aleksandr Sumerkin. Dana Point, CA: Ardis, 1996: 60-76.

Brodskii Iosif. "8-e dekabria 1995 g. V. P. Golyshevu". Novaia gazeta 35 (2000), 22 maia: 23.

Bui Vasilii. Russkaia zavetnaia idiomatika: Veselyi slovar' narodnykh vyrazhenii. Red.: d. f. n., prof. A. N. Baranov i d. f. n., prof. D. O. Dobrovol'skii. Izd. 2-e, ispr. i dop. M.: Al'ta-Print, 2005.

Carey Claude. Les proverbes érotiques russes: Études de proverbes recueillis et non-publiés par Dal' et Simoni. Slavistic Printings and Reprintings 88. The Hague; Paris: Mouton, 1972.

Chereiskii L. A. Pushkin i ego okruzhenie. 2-e izd., dop. i pererab. L.: Nauka, 1989.

Chuprinin S. I. “Zhizn' po poniatiiam”. Znamia 12 (2004): 140-155.

Dahl V. I. "[Reveiew of]: Opyt Oblastnogo velikorusskogo slovaria, izdannyi Vtorym otdeleniem Imperatorskoi Akademii Nauk. 1852 g." Vestnik Imperatorskogo Russkogo Geograficheskogo Obshchestva 6.1 (1852), otd. IV: 1-72.

Dahl V. I. "Uslovnyi yazyk peterburgskikh moshennikov, izvestnyi pod imenem muzyki ili baikovogo yazyka”. Publikatsiia i vstup. stat'ia A. L. Toporkova. Voprosy yazykoznaniia 1 (1990): 133-137.

Dahl V. I. Tolkovyi slovar' zhivogo velikorusskogo yazyka. Ch. I-IV. M.: V tipografii A. Semena, 1863-1866.

Dahl V. I. Poslovitsy russkogo naroda: Sbornik poslovits, pogovorok, rechenii, prislovii, chistogovorok, pribautok, zagadok, poverii i proch. M.: V Universitetskoi tipografii, 1862.

Dahl V. I., Baudouin-de-Courtenay I. A. Tolkovyi slovar' zhivogo velikorusskogo yazyka Vladimira Dalia. 3-e, ispr. i znachitel'no dop., izd. Pod red. prof. I. A. Boduena-de-Kurtene. T. I-IV. SPb.; M.: M. O. Vol’f, 1903-1909.

DBG $=$ Drevnerusskie berestianye gramoty. http://gramoty.ru/birchbark/

Dostoevskii F. M. Polnoe sobranie sochinenii v 30 tomakh. T. 21. L.: Nauka, 1980.

Dreizin Felix, Priestly Tom. "A Systematic Approach to Russian Obscene Language". Russian Linguistics 6.2 (1982): 233-249.

Eikhenbaum B. M. "Literaturnaia domashnost'." B. Eikhenbaum. Moi vremennik: Slovesnost', nauka, kritika, smes'. L.: Izdatel'stvo pisatelei v Leningrade, 1929: 82-86. Also published as "Predislovie" in: Aronson M., Reiser S. Literaturnye kruzhki i salony. Red. i predislovie B. M. Eikhenbauma. L.: Priboi, 1929: 3-7.

Ermen Ilse. Der obszöne Wortschatz im Russischen: Etymologie - Wortbildung - Semantik Funktionen. Specimina Philologiae Slavicae 98. München: O. Sagner, 1993.

Esenin S. A. Polnoe sobranie sochinenii v semi tomakh. T. 6. M.: Nauka; Golos, 1999.

ESSYa = Etimologicheskii slovar' slavianskikh yazykov: Praslavianskii leksicheskii fond. Pod red. chl.-korr. AN SSSR O. N. Trubacheva. M.: Nauka, 1975. Vyp. 2; 1979. Vyp. 6; 1981. Vyp. 8; 1990. Vyp. 16; 1994. Vyp. 20.

Gendelev-Khermonskii Mikhail Sam’iuelevich. "Bella Tristia". Solnechnoe spletenie, № 1. Jerusalem, 1998: 101-103. 
Gorbachevich K. S. Russkii sinonimicheskii slovar'. SPb.: ILI RAN, 1996.

Grachev M. A. "Sotsial'nye dialekty v 'Tolkovom slovare zhivogo velikorusskogo yazyka' V. I. Dalia". Vestnik Nizhegorodskogo gosudarstvennogo universiteta im. N. I. Lobachevskogo 6/2 (2013): 64-68.

Guber P. K. Don-Zhuanskii spisok Pushkina. Glavy iz biografii s 9-iu portretami. Pb.: Izdatel'stvo "Petrograd", 1923.

Gudzii N. K. "Protopop Avvakum kak pisatel' i kak kul'turno-istoricheskoe yavlenie". Zhitie protopopa Avvakuma im samim napisannoe i drugie ego sochineniia. [M.]: Academia, 1934: 7-59.

Hamp Eric P. "Albanian pidh : Slavic peizdla' ". International Journal of Slavic Linguistics and Poetics 11 (1968): 25-26.

Iezuitova R. V. “Rabochaia tetrad’ Pushkina PD, № 836 (Istoriia zapolneniia)”. Pushkin: Issledovaniia i materialy 14 (1991): 121-147.

Ivanov Viach. Vs. Lingvistika tret'ego tysiacheletiia: Voprosy $k$ budushchemu. M.: Yazyki slavianskoi kul'tury, 2004.

Jakobson Roman. "New Slavic Etymological Dictionaries". Word 8.4 (1952): 387-394.

Jakobson R. O. "Morfologicheskie nabliudeniia nad slavianskim skloneniem (sostav russkikh padezhnykh form)". Roman Jakobson. Selected Writings. Vol. II: Word and Language. The Hague; Paris: Mouton, 1971: 154-183.

Kabronskii V. [Kozlovskii Vladimir]. Nepodtsenzurnaia russkaia chastushka. Podgot. teksta, vvedenie i primechaniia V. Kabronskogo. Predislovie prof. V. Raskina. New York: Russica Publishers, 1978.

Kibirov Timur. "Poslanie L. S. Rubinshteinu”. Sintaksis, № 26. Paris, 1989a: 111-121.

Kibirov Timur. "Tri poslaniia: Otryvki iz poemy”. Vremia i my, № 197. New York, 1989b: 100110.

Kireev N. I., Sapogov I. A. "O nekotorykh terminakh naivnoi venerologii ot Pushkina do Boduena". Zeitschrift für slavische Philologie (in print).

Kirilina A. V. Eshche odin aspekt znacheniia obstsennoi leksiki. Vestnik Tambovskogo universiteta. Seriia: Gumanitarnye nauki 4 (1998): 13-16.

Kovalev Manuela. "From an unprintable to a printable language of literature? Russian obscene language in late and post-Soviet literary cultures". Russian Journal of Communication 6.2 (2014): 113-126.

Kovshova M. L. Semantika i pragmatika evfemizmov: Kratkii tematicheskii slovar' sovremennykh russkikh evfemizmov. M.: Gnozis, 2007.

Kovshova M. L. "Evfemizmy i frazeologizmy: ustoichivye struktury v aspekte evfemizatsii". Vestnik Moskovskogo gosudarstvennogo oblastnogo universiteta. Seriia: Russkaia filologiia 14 (2019): 35-48.

Lerner N. O. "Stikhotvornaia skladchina Pushkina i Denisa Davydova (Novoe chetverostishie Pushkina)". Pushkin i ego sovremenniki 36 (1923): 21-25.

Levicheva T. I. Pis'ma A. S. Pushkina Yuzhnogo perioda (1820-1824). M.: Nauka, 2001.

Levin Yu. I. "Ob obstsennykh vyrazheniiakh russkogo yazyka". Russian Linguistics 10.1 (1986): $61-72$.

Likhachev D. S. "Argoticheskie slova professional'noi rechi”. Razvitie grammatiki i leksiki sovremennogo russkogo yazyka. M.: Nauka, 1964: 311-359.

Lotman Ju. M. Aleksandr Sergeevich Pushkin. Seriia "Biografiia pisatelia". L.: Prosveshchenie, 1981.

Lotman Mikhail. “Ëksel'-moksel', ëlki-palki, (h)uina-muina i prochie shtuchki-driuchki”. Matica Srpska Journal of Slavic Studies 92 (2017): 641-673.

Lunt Horace G. "Slavic *jbgra 'Dance, Game, Play'." Papers in Slavic Philology 1. In Honor of James Ferrell. Edited by Benjamin A. Stolz. Ann Arbor: Michigan Slavic Publications, 1977: $172-177$.

Mikhailova N. I. '“Svodnia grustno za stolom...' (K kommentariiu stikhotvoreniia A. S. Pushkina)". Vremennik Pushkinskoi komissii 29 (2004) 198-201.

Minlos F. R. "Netochnaia reduplikatsiia kak sredstvo vyrazheniia znacheniia reprezentativnoi mnozhestvennosti". Komp'iuternaia lingvistika i intellektual'nye tekhnologii: Trudy Mezhdunarodnogo seminara "Dialog'2002" (Protvino, 6-11 iiunia 2002 g.). T. 1. M.: RGGU, 2002: 291-295. 
Minlos F. R. "Rifmovannye sochetaniia v russkom fol'klore: Reduplikatsiia i parnye slova". Russkii yazyk v nauchnom osveshchenii 9 (2005): 96-115.

Minorsky V. "Khāqānī and Andronicus Comnenus". Bulletin of the School of Oriental and African Studies, University of London 11.3 (1945): 550-578.

Mokienko V. M. "Russkaia brannaia leksika: Tsenzurnoe i netsenzurnoe". Rusistik $=$ Rusistika 11/12 (1994): 50-73.

Morozov A. A. "Russkaia stikhotvornaia parodiia". Russkaia stikhotvornaia parodiia (XVIII nachalo $X X$ v.). (Biblioteka poeta. Bol'shaia seriia). L.: Sovetskii pisatel', 1960: 5-88.

Muratov D. A. "Iavlenie est', i slovo est'." Novaia gazeta 78/2655 (2017), 21 iiulia: 21.

Nemirov Miroslav. Nekotorye stikhotvoreniia, raspolozhennye po alfavitu. Kontseptsiia i dizain: Aleksandr Florenskii. SPb.: Krasnyi matros, 1999.

NKRYa = Natsional'nyi korpus russkogo yazyka. https://ruscorpora.ru/

Nordstet Ivan. Rossiiskii, s nemetskim i frantsuzskim perevodami, slovar'. Ch. I-II. SPb.: I. K. Shnor, 1780-1782.

Oguibénine Boris. L'héritage du lexique indo-européen dans le vocabulaire russe: Compléments au Dictionnaire étymologique de la langue russe de M. Vasmer. Paris: Institut d'études slaves, 2016.

Osipov B. I. "Zametki po povodu otrazheniia tabuirovannoi leksiki v boduenovskikh izdaniiakh "Tolkovogo slovaria zhivogo velikorusskogo yazyka" V. I. Dalia". Acta Universitatis Szegediensis de Attila József Nominatae. Dissertationes Slavicae. Sectio linguistica 22 (1991): $31-49$.

Panasiuk I. L. "Semanticheskie i kommunikativnye osobennosti fenomena tabu". "Zlaia laia maternaia...”. Sbornik statei pod red. V. I. Zhel'visa. M.: Ladomir, 2005: 54-68.

Panchenko A. A. "Maternaia bran' v religioznom kontekste". "Zlaia laia maternaia...". Sbornik statei pod red. V. I. Zhel'visa. M.: Ladomir, 2005: 138-161.

Paperno I. A. "O dvuiazychnoi perepiske pushkinskoi pory". Uchenye zapiski Tartuskogo gosudarstvennogo universiteta 358 (1975): 148-156.

Pedersen Holger. "Litauisch skujà". Jagić-Festschrift: Zbornik u slavu Vatroslava Jagića. Berlin: Weidmannsche Buchhandlung, 1908: 218-219.

Pen'kovskii A. B. Zagadki pushkinskogo teksta i slovaria: Opyt filologicheskoi germenevtiki. M.: Yazyki slavianskikh kul'tur, 2005.

Pil'shchikov I. A. "Parodiia i satira v kontekste sporov o yazyke (XVIII—nachalo XIX v.)". Logicheskii analiz yazyka: Yazykovye mekhanizmy komizma. Otv. red. N. D. Arutiunova. M.: Indrik, 2007: 56-69.

Pilshchikov Igor. "If Only Pushkin Had Not Written This Filth': The Shade of Barkov and Philological Cover-ups". Taboo Pushkin: Topics, Texts, Interpretations. Ed. by Alyssa Dinega Gillespie. Madison: University of Wisconsin Press, 2012: 159-184.

Pilshchikov I. A. "Russkaia obstsennaia idiomatika v XIX i XX stoletiiakh". Substandart v russkom yazyke. Pod red. A. K. Birikha i M. A. Krongauza. Berlin: Peter Lang, 2022 (forthcoming).

Pilshchikov I., Ioffe D. "Russkii mat: vchera, segodnia, zavtra”. Matica Srpska Journal of Slavic Studies 100 (2021): 691-707.

Pil'shchikov I., Koniaev A. "Lenta.ru razobralas' v proiskhozhdenii russkogo mata”. http://lenta. ru/articles/2013/04/02/mat/

Pil'shchikov I. A., Shapir M. I. A. S. Pushkin. Ten' Barkova: Teksty. Kommentarii. Ekskursy. Izd. podgot. I. A. Pil'shchikov i M. I. Shapir. M.: Yazyki slavianskoi kul'tury, 2002.

Pil'shchikov I. A., Shapir M. I. "Eshche raz ob avtorstve ballady Pushkina 'Ten' Barkova'." Izvestiia Rossiiskoi akademii nauk. Seriia literatury i yazyka 64.3 (2005): 41-52.

Pilshchikov Igor, Shapir Maksim. "Avant-Gardism of the Classics and Classicality of the AvantGarde: Communication Strategies of Moscow Conceptualism in the Context of the Evolution of Styles in Russian Poetry from the Eighteenth to the Twentieth Century". Translated by Joseph Peschio and Igor Pilshchikov. Russian Literature 69.2/4 (2011): 383-392.

Plähn Jürgen. "Khuinia-muinia i tomu podobnoe". Russian Linguistics 11.1 (1987): 37-41.

Plutser-Sarno A. Yu. Bol'shoi slovar' mata. T. 1: Opyt postroeniia spravochno-bibliograficheskoi bazy dannykh leksicheskikh i frazeologicheskikh znachenii slova «khui». Materialy k slovariu russkogo mata. T. 2: Opyt postroeniia spravochno-bibliograficheskoi bazy dannykh 
leksicheskikh i frazeologicheskikh znachenii slova «pizda». SPb.; M.: Limbus Press, 20012005a.

Plutser-Sarno A. Yu. "Zametki o russkom mate". "Zlaia laia maternaia...”. Sbornik statei pod red. V. I. Zhel'visa. M.: Ladomir, 2005b: 162-205.

POS $=$ Pskovskii oblastnoi slovar's istoricheskimi dannymi. Pod red. L. A. Ivashko, I. S. Lutovinovoi, M. A. Tarasovoi. Vyp. 19. SPb.: Izdatel'stvo SPbGU, 2008.

Potapov S. M. Slovar' zhargona prestupnikov (blatnaia muzyka). Sostavil po noveishim dannym S. M. Potapov. M.: NKVD, 1927.

Priemysheva M. N. 'I. I. Sreznevskii ob ofenskom yazyke ('ofensko-russkii' i 'russko-ofenskii' slovari I. I. Sreznevskogo 1839 g. Iz sobraniia PFA RAN)". Acta Linguistica Petropolitana. Trudy instituta lingvisticheskikh issledovanii 3 (2007): 335-360.

Priemysheva M. N. Tainye i uslovnye yazyki v Rossii XIX v. Ch. I-II. SPb.: Nestor-Istoriia, 2009.

Prishvin M. M. Dnevniki, 1928-1929. M.: Russkaia kniga, 2004.

Prishvin M. M. Dnevniki, 1918-1919. M.: Russkaia kniga, 2008.

Propp V. Ya. Istoricheskie korni volshebnoi skazki. L.: Izdatel'stvo LGU, 1946.

Propp V. Ya. "Ritual'nyi smekh v fol'klore (Po povodu skazki o Nesmeiane)". V. Ya. Propp. Fol'klor i deistvitel'nost'. M.: Nauka, 1976: 174-204.

"Prozhito" = Tekstovyi korpus lichnykh dnevnikov "Prozhito". https://prozhito.org/

Pushkin A. S. Stikhotvoreniia Aleksandra Pushkina. Ch. 1. SPb.: V Tipografii Departamenta narodnogo prosveshcheniia, 1829.

Pushkin A. S. Boris Godunov. SPb.: V Tipografii Departamenta narodnogo prosveshcheniia, 1831.

Pushkin A. S. Sochineniia: Perepiska. T. I-III. SPb.: Tipografiia Imperatorskoi Akademii nauk, 1906-1909.

Pushkin A. S. Polnoe sobranie sochinenii. T. I-XVI. M.; L.: Izdatel'stvo AN SSSR, 1937-1949.

Pushkin A. S. Pis'ma kzhene. L.: Nauka, 1986.

Pushkin A. S. Rabochie tetradi. T. IV. SPb.; London: Institut russkoi literatury (Pushkinskii Dom) RAN, 1996.

Pushkin A. S. Polnoe sobranie sochinenii v 20 tomakh. T. 7. SPb.: Nauka, 2009.

Pushkin A. S. Polnoe sobranie sochinenii v 20 tomakh. T. 2, kn. 2. SPb.: Nauka, 2016.

Putilin I. D. "Uslovnyi yazyk Peterburgskikh moshennikov, izvestnyi pod imenem 'Muzyki' ili 'Baikovogo yazyka'.' Zapiski I. D. Putilina. Kn. 4. SPb.: Knigoizdanie I. A. Safonova, 1904: 261-267. Reprinted in: Sobranie russkikh vorovskikh slovarei v chetyrekh tomakh / Sost. i primech. V. Kozlovskogo. T. 1. New York: Chalidze Publications, 1983: 63-71.

PVS $=$ Pushkin $v$ vospominaniiakh sovremennikov. 3-e izd., dop. T. 1-2. SPb.: Akademicheskii proekt, 1998.

Ranchin A. M., Sapov N. Stikhi ne dlia dam: Russkaia netsenzurnaia poeziia vtoroi poloviny XIX veka. Izd. podgot. A. Ranchin i N. Sapov [S. I. Panov]. M.: Ladomir, 1994.

Rann James. "Review of: Taboo Pushkin: Topics, Texts, Interpretations. Ed. by Alyssa Dinega Gillespie. Madison: University of Wisconsin Press, 2012 [etc.]". Modern Language Review 109.2 (2014): 584-586.

Raskin Victor. "On Some Pecularities of Russian Lexikon". Papers from the Parasession on the Lexicon. Chicago Linguistic Society, April 14-15, 1978. Ed. by Donka Farkas, Wesley M. Jacobsen, Karol W. Todrys. Chicago: Chicago Linguistic Society; University of Chicago, 1978: 312-325.

Razvratnikov, Boris Sukitch. "Elementary Russian Obscenity”. Maledicta 3.2 (1979): 197-204.

Reiff Ch. Ph. Dictionnaire russe-français, dans lequel les mots russes sont classés par familles; ou Dictionnaire étymologique de la langue russe. T. I-II. SPb.: V Tipografii N. Grecha, $1835-1836$.

Rice James L. A Russian Bawdy Song of the Eighteenth Century. Slavic and East European Journal 20.4 (1976): 353-370.

Romashenkova T., Usmanov Z. "Mat gorodov russkikh". Itogi 39/485 (2005), 26 sentiabria. http:// www.itogi.ru/archive/2005/39/59573.html

Sapov N. Pod imenem Barkova: Eroticheskaia poeziia XVIII - nachala XX veka. Izd. podgot. N. Sapov [S. I. Panov]. M.: Ladomir, 1994.

Schruba Manfred. "Zur Spezifik der russischen obszönen Dichtungen des 18. Jahrhunderts (Barkoviana) vor dem Hintergrund der französischen Pornographie". Zeitschrift für slavische Philologie 59.1 (2000): 47-65. 
Shapir M. I. "Fenomen Baten'kova i problema mistifikatsii (Lingvostikhovedcheskii aspekt. 1-2)". Philologica 4 (1997): 85-139.

Shapir M. I. 'K semantike 'parodicheskogo balladnogo stikha' ('Ten' Barkova' v kontekste polemiki o starom i novom sloge)". M. I. Shapir. Universum versus: Yazyk - stikh - smysl v russkoi poezii XVIII-XX vekov. Kn. 1. M.: Yazyki russkoi kul'tury, 2000: 192-223.

Shapir M. I. "Barkov i Derzhavin: Iz istorii russkogo burleska”. A. S. Pushkin. Ten' Barkova: Teksty. Kommentarii. Ekskursy. Izd. podgot. I. A. Pil'shchikov i M. I. Shapir. M.: Yazyki slavianskoi kul'tury, 2002: 397-457.

Slovar' RYa XVIII = Slovar' russkogo yazyka XVIII veka. Vyp. 2. L.: Nauka, 1984.

Solzhenitsyn A. I. "Odin den' Ivana Denisovicha”. Novyi mir 11 (1962): 8-74.

Sreznevskii I. I. Materialy dlia slovaria drevne-russkogo yazyka po pis'mennym pamiatnikam. T. I-III. SPb.: Tipografiia Imperatorskoi Akademii nauk, 1893-1903.

Taranovsky Kiril. "The Rhythmical Structure of the Notorious Russian Poem Luka". International Journal of Slavic Linguistics and Poetics 25/26 (1982): 429-432.

Timroth Wilhelm von. Russische und sowjetische Soziolinguistik und tabuisierte Varietäten des Russischen (Argot, Jargons, Slang und Mat). Slavistische Beiträge 164. München: O. Sagner, 1983.

Toporkov A. L. Russkii eroticheskii fol'klor. Sost. i nauch. red. A. L. Toporkov. M.: Ladomir, 1995.

Trubachev O. N. "Iz raboty nad russkim Fasmerom: K voprosam teorii i praktiki perevoda". Voprosy yazykoznaniia 6 (1978): 15-24.

Trunin M. V. "Domashniaia semantika v fel'etonakh A. V. Druzhinina: Kak poniat' 'Chernoknizhnikova'?". Matica Srpska Journal of Slavic Studies 92 (2017): 383-411.

Tsiavlovskii M. A. "Kommentarii”. A. S. Pushkin. Ten' Barkova: Teksty. Kommentarii. Ekskursy. Izd. podgot. I. A. Pil'shchikov i M. I. Shapir. M.: Yazyki slavianskoi kul'tury, 2002: 164-299.

Ushakov D. N. Tolkovyi slovar' russkogo yazyka. Pod red. prof. D. N. Ushakova. T. I. M.: Gosudarstvennyi institut "Sovetskaia entsiklopediia"; OGIZ, 1935.

Uspenskii A. A. "Reestr slovam Ofenskogo narechiia". Trudy Obshchestva liubitelei Rossiiskoi slovesnosti pri Imperatorskom Moskovskom universitete 20 (1820): 239-242.

Uspenskii B. A. "Religiozno-mifologicheskii aspekt russkoi ekspressivnoi frazeologii". Struktura teksta - 81: Tezisy simpoziuma. M.: Institut slavianovedeniia i balkanistiki AN SSSR, 1981: 49-53.

Uspenskii B. A. "Mifologicheskii aspekt russkoi ekspressivnoi frazeologii". B. A. Uspenskii. Izbrannye trudy. T. 2: Yazyk i kul'tura. M.: Gnozis, 1994: 53-128.

Uspenskii B. A. “'Zavetnye skazki' A. N. Afanas'eva”. Anti-mir russkoi kul'tury: Yazyk. Fol'klor. Literatura. Sost. N. A. Bogomolov. M.: Ladomir, 1996: 143-164.

Vasmer Max. Russisches etymologisches Wörterbuch. Bd. I-III. Heidelberg: C. Winter, 1953-1958.

Vasmer M. Etimologicheskii slovar' russkogo yazyka. Per. s nem. i dop. O. N. Trubacheva. T. I-IV. M.: Progress, 1964-1973.

Veselovskaia T. M. “Kto takie lokhi?”. Russkaia rech' 1 (2001): 55-58.

Vinogradov V. V. Yazyk Pushkina: Pushkin i istoriia russkogo literaturnogo yazyka. M.; L.: Academia, 1935.

Vinokur G. O. “"Boris Godunov': [Kommentarii]”. A. S. Pushkin. Polnoe sobranie sochinenii. T. VII (“probnyi"). L.: Izdatel'stvo AN SSSR, 1935: 385- 505.

Vinokur G. O. "Iazyk 'Borisa Godunova'.” G. O. Vinokur. Izbrannye raboty po russkomu yazyku. M.: Uchpedgiz RSFSR, 1959: 301-327.

Voloshinov V. N. Marksizm i filosofiia yazyka: Osnovnye problemy sotsiologicheskogo metoda $v$ nauke o yazyke. Izd. 2-e. L.: Priboi, 1930.

Vygotskii L. S. Myshlenie i rech': Psikhologicheskie issledovaniia. M.; L.: Sotsekgiz, 1934.

[Weißman E.] Teutsch-Lateinisch- und Rußisches Lexikon, samt denen Unfangs-Gründen der Rußischen Sprache = Nemetsko-latinskii i ruskii lexikon kupno s pervymi nachalami ruskago yazyka. [Trans.: I. I. Il'inskii, I. P. Satarov i I. S. Gorlitskii]. SPb.: Tipografiia Imperatorskoi Akademii nauk, 1731.

Yanin V. L., Zalizniak A. A., Gippius A. A. Novgorodskie gramoty na bereste. T. 12: (iz raskopok 2001-2014 gg.). M.: Yazyki slavianskoi kul'tury, 2015.

Yurganov A. L. "Iz istorii tabuirovannoi leksiki: Chto takoe 'bliad" i kto takoi 'bliadin syn' v kul'ture russkogo srednevekov'ia”. Odissei. Chelovek v istorii. M.: Nauka, 2000: 194-206. 
Zalizniak A. A. Ot praslavianskoi aktsentuatsii k russkoi. M.: Nauka, 1985.

Zalizniak A. A. "Popravki i zamechaniia k chteniiu ranee opublikovannykh berestianykh gramot". Yanin V. L., Zalizniak A. A. Novgorodskie gramoty na bereste. T. 10: (iz raskopok 19901996 gg.). M.: Russkie slovari, 2000: 82-122.

Zalizniak A. A. "K voprosu ob aktsentnoi evoliutsii enklinomenov v russkom yazyke". Yazyk. Konstanty. Peremennye: Pamiati Aleksandra Evgen'evicha Kibrika. SPb.: Aleteiia, 2014: 269-276.

Zalizniak A. A. Drevnerusskoe udarenie: Obshchie svedeniia i slovar'. 2-e izd., rasshirennoe i pererab. M.: YaSK, 2019.

Zalizniak A. A., Yanin V. L. "Berestianye gramoty iz novgorodskikh raskopok 2005 g." Voprosy yazykoznaniia 3 (2006): 3-13.

Zhel'vis V. I. Pole brani: Skvernoslovie kak sotsial'naia problema. Izd. 2-e, pererab. i dop. M.: Ladomir, 2001.

Zhivov V. M. Yazyk i kul'tura v Rossii XVIII veka. M.: Shkola "Yazyki russkoi kul'tury", 1996.

Zhivov V. M. "KhOU-t'-I: Ob idiosinkraticheskikh faktorakh pri vybore morfologicheskikh variantov". V. M. Zhivov. Vostochnoslavianskoe pravopisanie XI-XIII veka. M.: Yazyki slavianskoi kul'tury, 2006: 200-224.

Zholkovskii Aleksandr. Erosiped i drugie vin'etki. M.: Vodolei, 2003.

Zmeev L. F. Russkie vrachebniki: Issledovanie v oblasti nashei drevnei vrachebnoi pis'mennosti. (Pamiatniki drevnei pis'mennosti CXII). SPb.: Tipografiia V. F. Demakova, 1895.

Zorin A. L. "Legalizatsiia obstsennoi leksiki i ee kul'turnye posledstviia". Anti-mir russkoi kul'tury: Yazyk. Fol'klor. Literatura. Sost. N. A. Bogomolov. M.: Ladomir, 1996: 121-139.

Zykov V., Kondrat'ev A. "Roskomnadzor nakazhet SMI tol'ko za chetyre maternykh slova". Izvestiia (2013), 25 dekabria. https://iz.ru/news/563178

Игор Пиљшчиков

\section{РУСКЕ ПСОВКЕ: ШТА ЗНАМО О ЮИМА? \\ (О ПОРЕКЛУ И ФУНКЦИЈАМА РУСКИХ ОПСЦЕНИХ ИДИОМА)}

\section{Резиме}

У чланку се расправља о дијахронијским променама у морфологији, акцентологији, семантици и стилистици кроз које су прошли руски опсцени идиоми. Утврђено је да су се до краја XIX века у фолклору, нецензурисаној књижевности и свакодневном говору опсцене речи користиле углавном у директном, односно материјалном значењу, а број речи насталих коришћењем основних опсцених коренова био је ограничен. Главни механизми опсцених иновација у XX-XXI веку постали су метафоризација (слободан пренос значења) и прономинализација (стицање контекстуалних значења). Они су довели до деривационе експлозије, када је постало могуће формирати стотине нових опсцених речи из веома ограниченог броја коренова. У исто време, неке речи из старог опуса псовки испале су из савремене употребе. Други важан механизам “формирања псовки” јесу секвенцијални и / или преклапајући процеси дисфемизације и еуфемизације, који се огледају у промени лексичко-семантичке и акценатске парадигме неких опсцених речи и њихових еуфемизама. Истовремено, примери анафоричке редупликације, која се нагло појачала у последњих пола века, срећу се већ у текстовима прве половине XIX века. У чланку се такође испитује еволуција функција псовки у књижевности XVIII-XX века, а нарочито употреба псовки у делима Баркова, Пушкина и Бродског.

Кључне речи: руски опсцени идиоми, дијахронијске промене у морфологији, акцентологији, семантици и стилистици псовки, механизми иновација, функције псовки у књижевности XVIII-XX века. 